\title{
Structure of lamprophyres: a discriminant marker for Variscan and Alpine tectonics in the Argentera-Mercantour Massif, Maritime Alps
}

\author{
Marco Filippi ${ }^{1,2, *}$, Davide Zanoni ${ }^{1}$, Guido Gosso ${ }^{1}$, Jean-Marc Lardeaux ${ }^{2,3}$, Chrystèle Verati $^{2}$ and \\ Maria Iole Spalla ${ }^{1}$ \\ ${ }^{1}$ Dipartimento di Scienze della Terra “A. Desio”, Università degli Studi di Milano, Via Mangiagalli 34, 20133 Milan, Italie \\ ${ }^{2}$ UMR Géoazur, Université Côte d'Azur, Observatoire de la Côte d'Azur, CNRS, IRD, 250 Rue A. Einstein, Sophia-Antipolis 06560 \\ Valbonne, France \\ ${ }^{3}$ Centre for Lithospheric Research, Czech Geological Survey, Klàrov 3, 11821 Prague 1, République Tchèque
}

Received: 26 February 2019 / Accepted: 8 October 2019

\begin{abstract}
Structural and microstructural analyses are carried out in two sites of the Argentera-Mercantour Massif, Valscura and Val du Haut Boréon, where swarms of lamprophyres intruded into Variscan migmatites and early Permian granitoids. Efforts aim at defining the structural relationships between lamprophyres and country rocks, and at constraining the structural and metamorphic evolution the dykes record. Mesoscale structural data are synthesised in geologic maps originally surveyed at 1/10000 scale, supported by formsurface maps at $1 / 100$ scale. The lamprophyres are magnesian, calc-alkalic to alkali-calcic, and metaluminous; they emplaced at very shallow crustal levels intersecting three generations of ductile structures in the host migmatites (D1, D2, D3). Epidote- and actinolite-bearing mineral assemblages result from late-intrusive hydrothermal circulation that has not affected the host rocks. Mylonitic shear zones of Alpine age (D4) are continuous through migmatites, granites, and lamprophyres: in these latter, they are supported by albite, actinolite, biotite, chlorite, epidote, phengite, and titanite. This detailed multi-scale structural analysis, coupled with major and trace elements geochemistry, highlights two main results: i) the lamprophyres, which post-date both the late- to post-collisional "high-Mg" and the "low-Mg" granitoids, reflect the last magmatic event in the Argentera-Mercantour Massif related to the Permian-Triassic lithospheric thinning; ii) the metamorphic assemblages that support the Alpine shear zones in the lamprophyres are consistent with the transition between the greenschist and amphibolite facies conditions.
\end{abstract}

Keywords: External Crystalline Massifs / multiscale structural analysis / Variscan deformation / Alpine deformation and metamorphism / late- to post-Variscan magmatism / high-K calc-alkaline lamprophyres

Résumé - Structure des lamprophyres: un marqueur discriminant des tectoniques Varisque et Alpine dans le Massif de l'Argentera-Mercantour, Alpes Maritimes. Des analyse structurales et microstrucrurales ont menées dans deux secteurs clés du massif de l'Argentera-Mercantour, la zone de Valscura et la zone du Val du Haut Boréon, où des réseaux de filons de lamprophyres intrudent des migmatites Varisques et des granites d'âge Permien inférieur. Nous présentons et discutons les résultats d'une analyse détaillée, d'une part, des relations entre filons de lamprophyres et roches encaissantes et, d'autre part, des évolutions structurales et métamorphiques de ces filons. Les données structurales observables à la mésoéchelle sont synthétisées dans des cartes géologiques obtenues à l'échelle du 1/10 000, appuyées par des analyses géométriques détaillées à l'échelle du 1/100. Les lamprophyres sont des roches magnésiennes, calco-alcalines à alcalino-calciques et moyennement alumineuses, qui sont affectées par un évolution hydrothermale tardi-magmatique marquée par le remplacement statique des phases magmatiques par des associations à épidote et actinote. Dans les deux zones considérées, les lamprophyres se sont mis en place à un niveau structural très superficiel et recoupent trois générations de structures superposées identifiées dans le complexe migmatitique (D1, D2, D3). Les zones mylonitiques Alpines (D4) qui sont localisées recoupent et décalent les filons de lamprophyres. Ces structures sont soulignées par une association minéralogique à albite, amphibole, biotite, chlorite, epidote, phengite et

*Corresponding author: marco.filippi@unimi.it 
sphène. Cette analyse structurale détaillée et multi-échelles, associée à l'étude de la géochimie des éléments majeurs et des éléments en traces, met en évidence deux résultats principaux : i) les lamprophyres représentent le dernier événement magmatique enregistré dans le Massif de l'Argentera-Mercantour. Il est postérieur aux granitoïdes tardi a post-collision «à forte» comme «à faible» teneur en $\mathrm{Mg}$, et est lié à l'amincissement lithosphérique d'âge Permo-Triasique; ii) les assemblages métamorphiques qui soulignent les zones de cisaillement Alpines dans les lamprophyres sont compatibles avec la transition entre les faciès des Schistes Verts et des Amphibolites.

Mots clés : Massifs Cristallins Externes / analyse structurale multi-échelles / déformation Varisque / déformation et métamorphisme Alpin / magmatisme tardi à post Varisque / lamprophyres calco-alcalins riches en $\mathrm{K}$

\section{Introduction}

Mafic dykes are structural and metamorphic markers of the first order for distinguishing between superposed tectonic and/ or metamorphic cycles in orogenic systems, as highlighted in pioneering to recent contributions (e.g. Myers, 1978; Mørk, 1985; Williams, 1985; Spalla et al., 2000; Baletti et al., 2012; Gosso et al., 2015; Zanoni et al., 2016). In the ArgenteraMercantour Massif, a portion of deep Variscan crust reactivated during the Alpine collision, swarms of pre-Alpine lamprophyres are known for over sixty years (Faure-Muret, 1955; Bortolami and Sacchi, 1968; Malaroda et al., 1970; Compagnoni et al., 2010). Since these lamprophyres intruded into Variscan migmatites and early Permian granitoids and were subsequently deformed and metamorphosed, they are appropriate markers to distinguish between Variscan and Alpine syn-metamorphic structures in the basement rocks of the Argentera-Mercantour Massif.

The purpose of this paper is to present and discuss the multiscale structural analysis we have carried out in two localities, Valscura and Val du Haut Boréon, where the lamprophyres are widespread. Major and trace element compositions are investigated to frame the Argentera-Mercantour lamprophyres in the record of the Permian and Triassic magmatism of the Southern Variscan belt.

\section{Geological outline}

\subsection{The late- to post-collisional magmatism in the Southern Variscan belt}

Two main magmatic cycles of late Carboniferous to Triassic ages are described in the Southern Variscan belt. The first cycle comprises calc-alkaline tonalites, granodiorites, and monzogranites, as well as metaluminous to peraluminous rhyolites and dacites (Cortesogno et al., 1998; Atzori et al., 2000; Paquette et al., 2003; Traversa et al., 2003; Gaggero et al., 2007; Romano et al., 2011; Rossi et al., 2015). The second cycle is of alkaline affinity and includes peralkaline to slightly peraluminous A-type granites and rhyolites, as well as alkaline diorites, andesites, basalts, and minor lamprophyres (Cortesogno et al., 1998; Traversa et al., 2003; Cocherie et al., 2005; Gaggero et al., 2007). Mafic and ultramafic layered complexes and transitional to tholeiitic basalts and andesites are generally ascribed to the alkaline cycle, although their ages are partially in overlapping with those of the calc-alkaline suites (Paquette et al., 2003; Cocherie et al., 2005).

Field relationships highlight that, in most of the cases, alkaline magmas intruded into the calc-alkaline magmatic suites and bimodal alkaline lavas are the youngest in the volcano-sedimentary sequences (Leroy and Cabanis, 1993; Cortesogno et al., 1998; Traversa et al., 2003; Dallagiovanna et al., 2009; Rossi et al., 2015). Moreover, the alkaline magmatism locally lasted up to Triassic times (Vatin-Pérignon et al., 1972; Vatin-Pérignon et al., 1974; Buffet and Aumaitre, 1979; Gaggero et al., 2007; Barca et al., 2010; Cirrincione et al., 2014; Cirrincione et al., 2016). A mantle contribution in the genesis of these magmatic rocks is undisputed (e.g. Rottura et al., 1998; Traversa et al., 2003; Gaggero et al., 2007; Renna et al., 2007; Duchesne et al., 2013; Cirrincione et al., 2016).

Composite calc-alkaline intrusives emplaced in Corsica at 308-304 Ma (U-Pb zircon dating, Paquette et al., 2003; Rossi et al., 2015) and were followed by calc-alkaline monzogranites, calc-alkaline volcano-sedimentary sequences, and transitional to tholeiitic mafic intrusives, dated between 293 and $279 \mathrm{Ma}$ (U-Pb zircon dating, Rossi et al., 2002; Paquette et al., 2003: Cocherie et al., 2005; Renna et al., 2007; Rossi et al., 2015). Similarly, the A-type granites of Corsica are dated between 290 and $278 \mathrm{Ma}$ (U-Pb zircon dating, Cocherie et al., 2005; Rossi et al., 2015).

In Sardinia, the calc-alkaline cycle started between 321 and $313 \mathrm{Ma}$, with apex at 311-307 Ma (U-Pb zircon dating; Casini et al., 2012). Here, calc-alkaline granodiorites and diorites emplaced between 295 to $286 \mathrm{Ma}$, whereas transitional to alkaline basalts came after at 254 to $248 \mathrm{Ma}$ (hornblende ${ }^{40} \mathrm{Ar} /{ }^{39} \mathrm{Ar}$ dating, Gaggero et al., 2007).

Alkali-calcic and calc-alkalic granites emplaced in the Maures-Tanneron Massif at around 300 Ma and were intruded by slightly younger calc-alkaline dolerite dykes (biotite and muscovite ${ }^{40} \mathrm{Ar} /{ }^{39} \mathrm{Ar}$ dating, Morillon et al., 2000; U-Pb zircon dating, Duchesne et al., 2013). A-type rhyolites and younger transitional tholeiitic lavas and dykes in the volcano-sedimentary sequence of the adjacent Estrél basin are dated between 278 and $264 \mathrm{Ma}\left({ }^{40} \mathrm{Ar}{ }^{39} \mathrm{Ar}\right.$ feldspar dating, Zheng et al., 1992; Poitrasson and Pin, 1998; Lapierre et al., 1999); whereas, in the Toulon basin, Middle Permian transitional tholeiitic to alkaline basalts post-date Lower to Middle Permian calc-alkaline rhyolites (Leroy and Cabanis, 1993). Middle to Upper Triassic alkaline to transitional basalts and late Triassic to early Jurassic tholeiites are also reported in Calabria and Sicily (Barca et al., 2010; Cirrincione et al., 2014; Cirrincione et al., 2016).

In the Alpine area, very few lamprophyres intruding ferriferous alkali-calcic granites of late Carboniferous ages are described in the Mont-Blanc and Aiguilles Rouges Massifs (von Raumer, 1987; Bussy et al., 2000). In the Pelvoux Massif, minor swarms of alkaline mafic dykes intersect Carboniferous granites and calc-alkaline diorite dykes, whereas alkaline volcaniclastics are interlayered in the Triassic sedimentary sequences (Vatin-Pérignon et al., 1972; Vatin-Pérignon et al., 1974; Buffet and Aumaitre, 1979). In the Ligurian basement, 


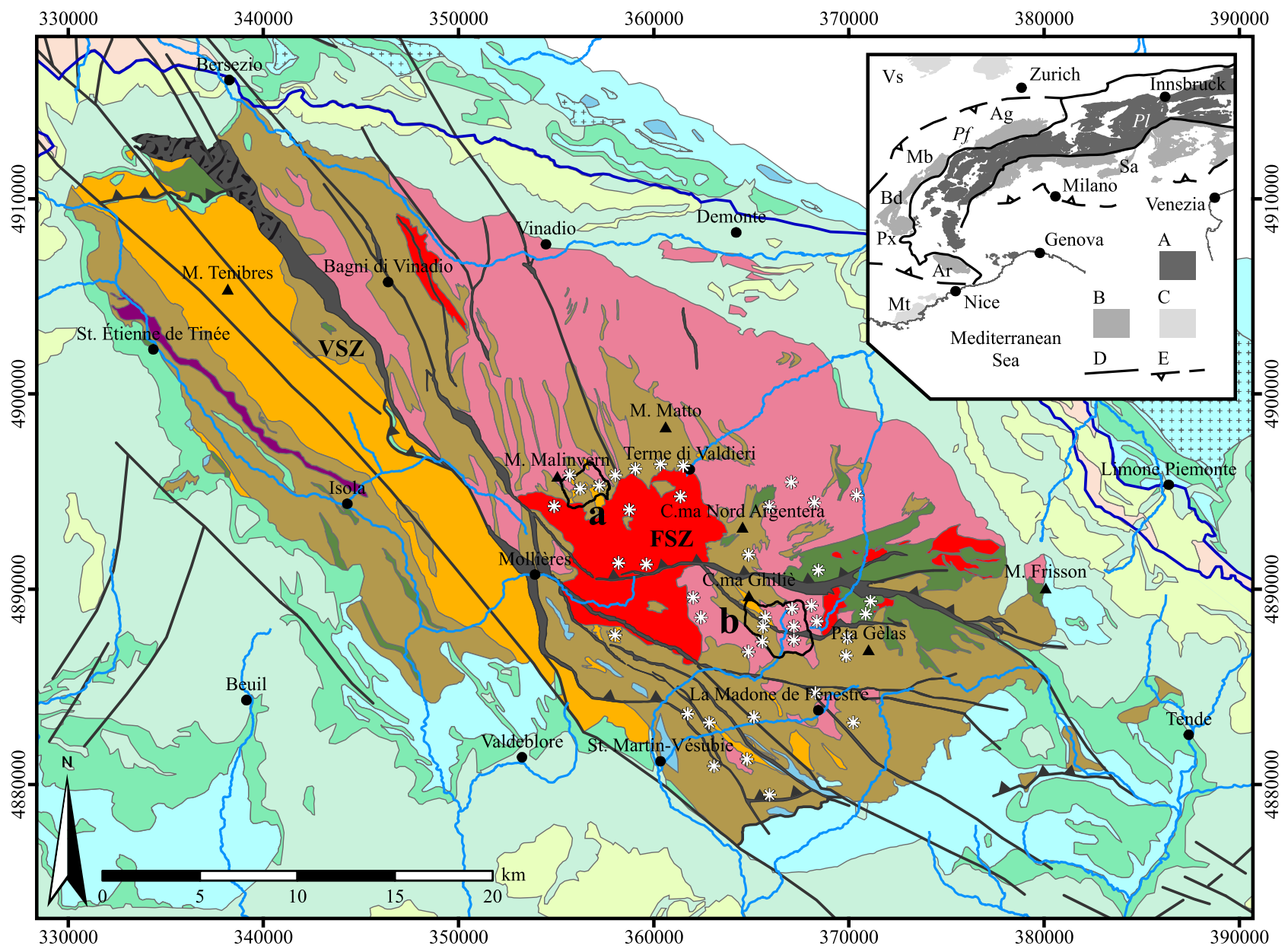

Alpine to post-Alpine rocks and structures

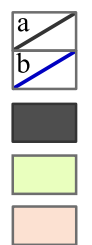

a: late- to post-Alpine faults; b: Penninic Front.

Greenschist facies mylonites. Tertiary foreland successions (Upper Cretaceous - Priabonian)

Helmintoid flysch (Cretaceous).

Late-Variscan to Mesozoic sequences

Limestones, marlstones, and shales (Lower Jurassic to Lower Cretaceous). $\square$ Limestones and dolomites (Middle to Upper Triassic); conglomerates, sandstones, and pelites (Lower Triassic). a: arkoses, conglomerates, pelites, and siliciclatic sandstones (Permian); b: porphyroids (Permian).

Carbonaceous schists, conglomerates, and siliciclastic sandstones (late Carboniferous).

\section{Varisican basement}

齿 Lamprophyres.

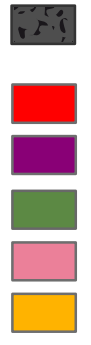

Amphibolite to greenschist facies mylonites.

\section{Granitoids}

Syn-tectonic diorites.

Amphibolites.

Crd-bearing anatexites.

Migmatitic orthogneisses and metagranitoids.

Migmatitic paragneisses (metapelites and metagreywackes).

Fig. 1. Simplified geologic map of the Argentera-Mercantour Massif (after Malaroda et al., 1970; Carosi et al., 2016; Gosso et al., 2019; and refs. therein). Black profiles highlight Valscura (a) and Val du Haut Boréon (b). Abbreviations: FSZ: Fremamorta Shear Zone; VSZ: Valletta Shear Zone (also known as Ferrere-Mollières Shear Zone). Projected coordinate system: WGS 84-UTM32N. Insert: tectonic sketch of the Alps: A: Variscan basement rocks into the axial zone of the Alps; B: Variscan basement rocks at the external margins of the Alps (Ag: Aar-Gothard Massif; Ar: Argentera-Mercantour Massif; Bd: Belledonne Massif; Mb: Mont Blanc Massif; Px: Pelvoux Massif; Sa: Southern Alps); C: Variscan basement rocks external to the Alpine fronts (Mt: Maures-Tanneron Massif, Vs: Vosges); D: lithospheric-scale structures delimiting the axial zone of the Alps (Pf: Penninic Front, Pl: Periadriatic Lineament); E: Alpine fronts.

calc-alkaline rhyolites, andesites, and rhyodacites of 286 to $272 \mathrm{Ma}$ are post-dated by alkaline rhyolites dated at $258.5 \pm 2.8 \mathrm{Ma}$ (Buzzi and Gaggero, 2008; U-Pb zircon dating, Dallagiovanna et al., 2009). Permian and Triassic calc-alkaline to alkaline intrusives and volcanics are also abundant in the Southern Alps (Giobbi Origoni et al., 1988; Sloman, 1989; Rottura et al., 1998; Garuti et al., 2001; Cassinis et al., 2007;
Schaltegger and Brack, 2007; Locmelis et al., 2016; Casetta et al., 2018; Zanoni and Spalla, 2018; Storck et al., 2019).

\subsection{The Argentera-Mercantour Massif}

The crystalline basement of the Argentera-Mercantour Massif (Fig. 1) consists of migmatitic orthogneisses, 
paragneisses, and amphibolites that include pre-anatectic relics of eclogites, high-pressure mafic granulites, ultramafites and calc-silicates (Faure-Muret, 1955; Malaroda et al., 1970; Blasi, 1971; Bortolami et al., 1974; Bogdanoff and Ploquin, 1980; Bogdanoff, 1986; Latouche and Bogdanoff, 1987; Paquette et al., 1989; Rubatto et al., 2001; Ferrando et al., 2008; Compagnoni et al., 2010; Rubatto et al., 2010). The widespread migmatisation, dated at $323 \pm 12 \mathrm{Ma}$, came after the emplacement of monzonite dykes at $332 \pm 3 \mathrm{Ma}$ (U-Pb zircon dating, Rubatto et al., 2001). These monzonites are part of "high-Mg number" suites of the External Crystalline Massifs (Debon and Lemmet, 1999), which are interpreted as products of a late-collisional event that involved melting of an enriched mantle source triggered by slab window or slab break-off (Banzet, 1987; von Raumer et al., 2014).

The late- to post-Variscan exhumation of the migmatitic complex is testified by the structural and metamorphic evolution of the Valletta Shear Zone (VSZ, Fig. 1), a mayor dextral transpressive mylonite that has been active between 330 and $314 \mathrm{Ma}$ during retrograde metamorphism (FaureMuret, 1955; Musumeci and Colombo, 2002; Corsini et al., 2004; Carosi et al., 2016; Simonetti et al., 2018). The surface exposition of the Argentera-Mercantour Massif is constrained by late Carboniferous to Permian siliciclastic sequences that unconformably rest on the migmatites (Faure-Muret, 1955; Malaroda et al., 1970; Bortolami et al., 1974). At the same time, sets of brittle structures accommodated the emplacement of the Central Granite (Boucarut, 1967; Compagnoni et al., 2010), whose age (292 $\pm 10 \mathrm{Ma}, \mathrm{Rb}-\mathrm{Sr}$ muscovite dating, Ferrara and Malaroda, 1969; 299-296 Ma, ${ }^{40} \mathrm{Ar} /{ }^{39} \mathrm{Ar}$ muscovite dating, Corsini et al., 2004) and composition match those of late- to post-Variscan "low-Mg number suites" of the External Massifs (Debon and Lemmet, 1999). However, rhyolites, dacites, and basalts in the sedimentary covers testify that magmatic activity in the Argentera-Mercantour Massif lasted, at least, through the Permian (Faure-Muret, 1955; Malaroda et al., 1970; Romain and Vernet, 1978). In the stratigraphic record, syn-extensional siliciclastic sequences of Permian age (Aicard et al., 1968; Delteil et al., 2003) were firstly followed by Middle to Upper Triassic evaporites and shallow-water limestones, and lately by the Lower Jurassic deepening successions of the European passive margin (FaureMuret, 1955; Malaroda et al., 1970; Lemoine et al., 1986; Dardeau, 1988).

In the Alpine framework, the Argentera-Mercantour Massif is a segment of thinned European crust shortened during the continental collision (Bogdanoff et al., 2000; BigotCormier et al., 2006; Schwartz et al., 2007; Schreiber et al., 2010; Lardeaux, 2014). The massif attained its maximum burial in the early Oligocene, by overthrusting of internally derived nappes (Kerckhove, 1969; Merle and Brun, 1984; Evans and Elliot, 1999; Ford et al., 1999; Simon-Labric et al., 2009; Sanchez et al., 2010). The VSZ was severely reactivated as a dextral strike-slip mylonite and several inverse shear zones, mainly E-W striking, developed in response to Alpine transpression (Corsini et al., 2004; Sanchez et al., 2011a; Simonetti et al., 2018).

An Alpine metamorphic event affecting Carboniferous covers and early Permian granitoids is described since Boucarut (1967). However, in the lack of structural and/or chronological markers, the Alpine metamorphic overprint in migmatites is hardly distinguishable from that coming along with the late-Variscan exhumation, as Bortolami et al. (1974) point out. ${ }^{40} \mathrm{Ar} /{ }^{39} \mathrm{Ar}$ ages of phengite crystals supporting greenschist facies mylonites constrain the Alpine metamorphism between 34 and $20 \mathrm{Ma}$ (Corsini et al., 2004; Sanchez et al., 2011a). In particular, the oldest Alpine shear zones (34 Ma) developed at $T=375 \pm 25^{\circ} \mathrm{C}$ and $P=0.7-0.9 \mathrm{GPa}$, whereas the youngest $(22-20 \mathrm{Ma})$ at $375 \pm 25^{\circ} \mathrm{C}$ and 0.4 $0.6 \mathrm{GPa}$ (Sanchez et al., 2011a). Thermobarometric estimates on Permian-Triassic meta-sedimentary rocks at the southern edge of the Argentera-Mercantour Massif confirm $T>300^{\circ} \mathrm{C}$ and $P>0.3 \mathrm{GPa}$ for the Alpine metamorphic event (Attal, 2000). The same shear zones, still keeping the same kinematics under brittle-ductile conditions, are accountable for the final exhumation of the basement rocks: exhumation below $150{ }^{\circ} \mathrm{C}$ occurred at $8 \mathrm{Ma}$ (Apatite FT dating) and this stage was followed by slower exhumation rates driven by the transcurrent tectonic context (Tricart et al., 2004; Bigot-Cormier et al., 2006; Baietto et al., 2009; Sanchez et al., 2010; Sanchez et al., 2011b; Leclère et al., 2014; Bauve et al., 2014).

\section{Principal rocks associations: high- resolution mapping}

\subsection{Valscura site}

The basement rocks of Valscura comprise migmatitic paragneisses, meta-granitoids and cordierite-bearing anatexites, with minor migmatitic amphibolites (Fig. 2). Some outcrops, in which lamprophyres are widely surfacing, are mapped in detail for highlighting structural and petrogenetic relationships with the country rocks (Fig. 3).

Millimetre-thick films of biotite, fine-grained trails of garnet and sillimanite, and quartz-feldspar leucosomes in centimetre-thick bands outline the migmatitic foliation in paragneisses (Fig. 4a). The migmatitic foliation in metagranitoids is, instead, supported by anastomosing films of biotite, and quartz-feldspar leucosomes occupy microlithons and strain shadow domains around porphyroclasts of igneous K-feldspar. Veins of cordierite-bearing leucosome crosscut the migmatitic foliation in both paragneisses and meta-granitoids. The anatexites are leucocratic rocks mainly composed of quartz + feldspar \pm cordierite leucosomes, which result from high degrees of partial melting. Disarticulated and convolute films of biotite support the migmatitic foliation in the anatexites. Chlorite, titanite, white-mica, and rare epidote replace migmatitic mineral assemblages in all the rock types.

Leucosomes and granitoids of different textures and compositions are hosted in the migmatites: fine-grained biotite-bearing granites outcrop between M. Malinvern and Laghi Superiori di Valscura, whereas coarse-grained twomica-bearing granites (i.e. the Central Granite) surface at C.ma del Tavels (Fig. 2). Afterwards, migmatites and granites were intruded by aplitic to pegmatitic dykes, consisting of plagioclase, quartz, K-feldspar, white mica with rare biotite and/or garnet, and, lastly, by swarms of lamprophyres.

The intrusive contacts between lamprophyres and country rocks are sharp and outlined by chilled margins (Fig. 4b). The lamprophyres that are less than a metre-thick are spessartites, with euhedral phenocrysts of amphiboles into a greenish aphanitic groundmass (Fig. 4c). Amphibole phenocrysts in 


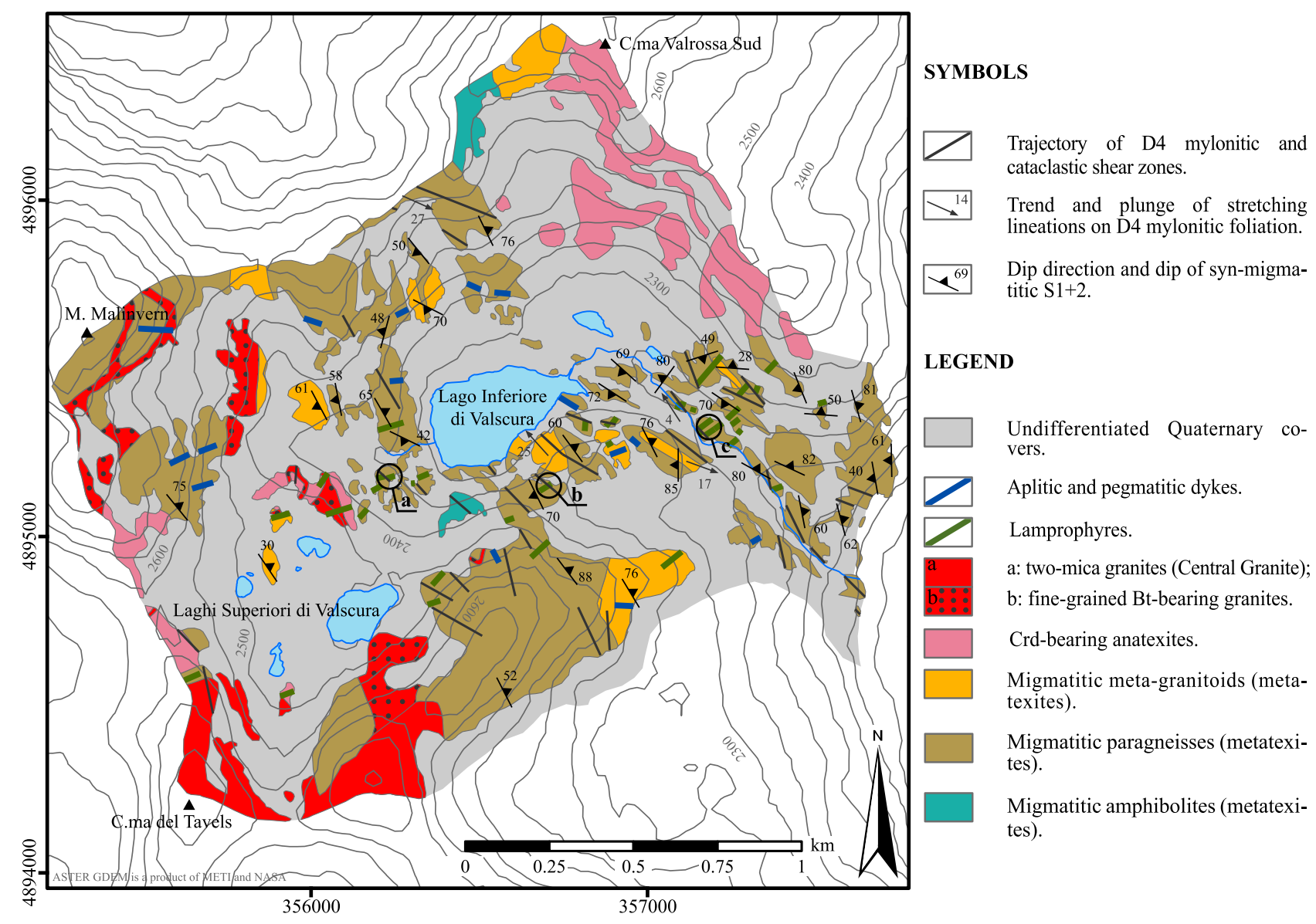

Fig. 2. Geo-structural map of Valscura ( $c f$. Fig. 1 for location), upgraded after Montani (2004). Projected coordinate system: WGS 84-UTM 32 N. Positions of outcrop scale form-surface maps at $1 / 100$ scale are reported ( $c f$. Fig. 3 ).

spessartites may show shape-preferred orientation (SPO) tracking a magmatic foliation; in other cases, they are randomly oriented, often in glomeroporphyric aggregates. Millimetresized vesicles are common in the external parts of the porphyritic dykes, and they can be either empty or filled by aggregates of plagioclase and minor amphibole, or by calcite. The thickest lamprophyres, classified as appinites according to IUGS (Le Maitre et al., 2002), are phaneritic, with randomly oriented crystals of amphibole, plagioclase, minor K-feldspar, and rare quartz. Sharp to lobate fragments of appinite may be enclosed into leuco-appinites, which consist of plagioclase, K-feldpsar, quartz, and minor amphibole: such internal structures suggest that mingling and magmatic brecciation occurred during their emplacement. Aggregates of chlorite and epidote widely replace igneous minerals in the lamprophyres (Fig. 4d), as well as early formed mineral assemblages in the country rocks close to the dyke walls. Very localised mylonitic shear zones crosscut migmatites, granitoids and lamprophyres. In the migmatites, these structures are supported by chlorite, phengite, minor biotite, and very rare actinolite (Figs. 2, 3 and 4e).

\subsection{Val du Haut Boréon site}

The migmatitic paragneisses of Val du Haut Boréon are locally interlayered with metre-thick layers of amphibolites and grade into diatexites and anatexites towards the eastern edge of the mapped area (Fig. 5); structures and supporting mineral assemblages are similar to those described in Valscura. Heterogeneously deformed migmatitic orthogneisses with granulite relics, already described as meta-volcanics by Colombo et al. (1993) and Rubatto et al. (2001), outcrop around C.ma Ghilié (Fig. 5). Cordierite-bearing pegmatites, white mica-bearing granite pockets, and aplite dykes are widespread in the migmatitic complex: all these intrusives are crosscut by the lamprophyres. Structural study of outcrops, where the lamprophyres display clear structural relationships with the country rocks, requests mapping at 1/100 scale (Fig. 6).

In Val du Haut Boréon, the lamprophyres show higher textural and compositional heterogeneities in comparison with those from Valscura, although they are characterised by chilled margins as well (Fig. 7a). Very rare grains of clinopyroxene, locally in glomeroporphyric aggregates, are found together with phenocrysts of amphibole in up to metre-thick and NW-SE striking spessartites. Vesicles, mainly filled by feldspar, igneous amphibole, or by calcite, are arranged in layers parallel to the dyke walls. A single E-W-striking dyke of 10 metres of thickness run through all the Val du Haut Boréon from its northwestern edge to Cime de l'Agnel (Fig. 5): at Lacs Bessons (Figs. 5 and 6) it displays a symmetrical structure with two metre-thick bands of melanocratic spessartites along its margins (Figs. 7a and 7b) and appinites and leuco-appinites at core (Fig. 7c). Melanocratic spessartites are formed by rounded to angular amphibole-rich 


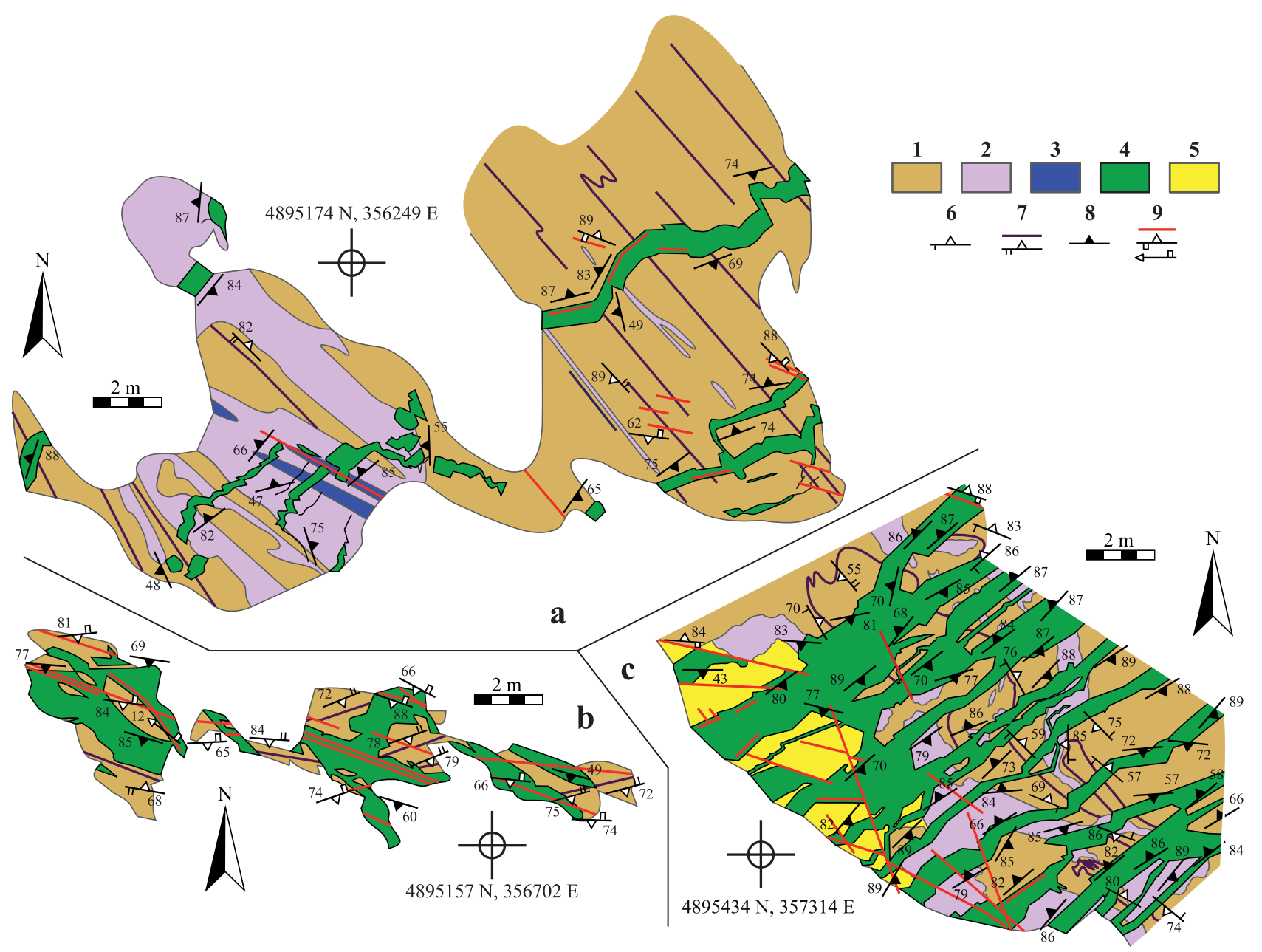

Fig. 3. Form-surface maps of selected outcrops in Valscura, mapped at 1/100 scale (locations are in Fig 2). Legend: 1: migmatitic paragneisses; 2: leucosome-rich domains; 3: amphibolite relics; 4: lamprophyres; 5 : migmatitic paragneisses whose rock forming minerals are pervasively replaced by epidote and chlorite; 6: trajectory, dip direction and dip of S1 foliation; 7: dip direction and dip of D2 axial plane and S2 foliation; 8: dip direction and dip of lamprophyre dyke walls; 9: trajectory, dip direction, and dip of D4 mylonitic to stylolitic foliation; trend and plunge of stretching lineation on D4 mylonitic foliation. Scale bars, north arrows, and geo-referenced points are assigned to each outcrop (projected coordinate system: WGS 84-UTM 32N).

domains of millimetre to centimetre size enclosed into a mesocratic matrix, and include several layers of vesicles. In the central part, lobate to angular enclaves of appinites are mingled together with leuco-appinites, as a consequence of different, but concomitant, magmatic pulses (Fig. 7c). Comb layers, outlined by phenocrysts of amphibole of centimetre size interlayred with fine-grained domains, divide the appinites from the melanocratic spessartites and define two metre-thick bands (Figs. 6 and 7d). Amphibole phenocrysts in comb layers are arranged in fanshaped aggregates, which are almost orthogonal with respect to the dyke walls. Locally, melanocratic spessartites are directly in contact with the appinites: here, clasts of comb layered appinites and melanocratic spessartites, which locally preserve chilled margins, are included in the central part of the dyke (Fig. 7e). NESW striking spessartite dykes intersect the external parts of the main dyke at the Lacs Bessons and intrusive contacts are lobate (Fig. 6); conversely, they seem to be coalescent with appinites and leuco-appinites at its core. Centimetre-thick leucocratic veins follow the margins of the main dyke and crosscut the melanocratic spessartites and, in few cases, the leuco-appinites (Figs. 7e and 7f). As well as in Valscura, igneous minerals are widely replaced by fine-grained aggregates of epidote and chlorite, which grew in spotted domains, mainly localised in coarse-grained appinite or in and around the leucocratic veins (Figs. 7c and 7f): such pervasive pseudomorphosis is not observed in the migmatites away from the dyke walls. Migmatites, granitoids, and lamprophyres are intersected by ductile to cataclastic shear zones (Figs. $7 \mathrm{~g}$ and $7 \mathrm{~h}$ ): the mineral assemblages that support mylonitic and stylolitic foliations in lamprophyres will be the topic of the next paragraphs.

\section{Finite strain pattern}

\subsection{Valscura site}

The pervasive structure developed in the migmatitic complex of Valscura is the composite fabric $\mathrm{S} 1+2$ that defines the boundaries between migmatitic paragneisses and 

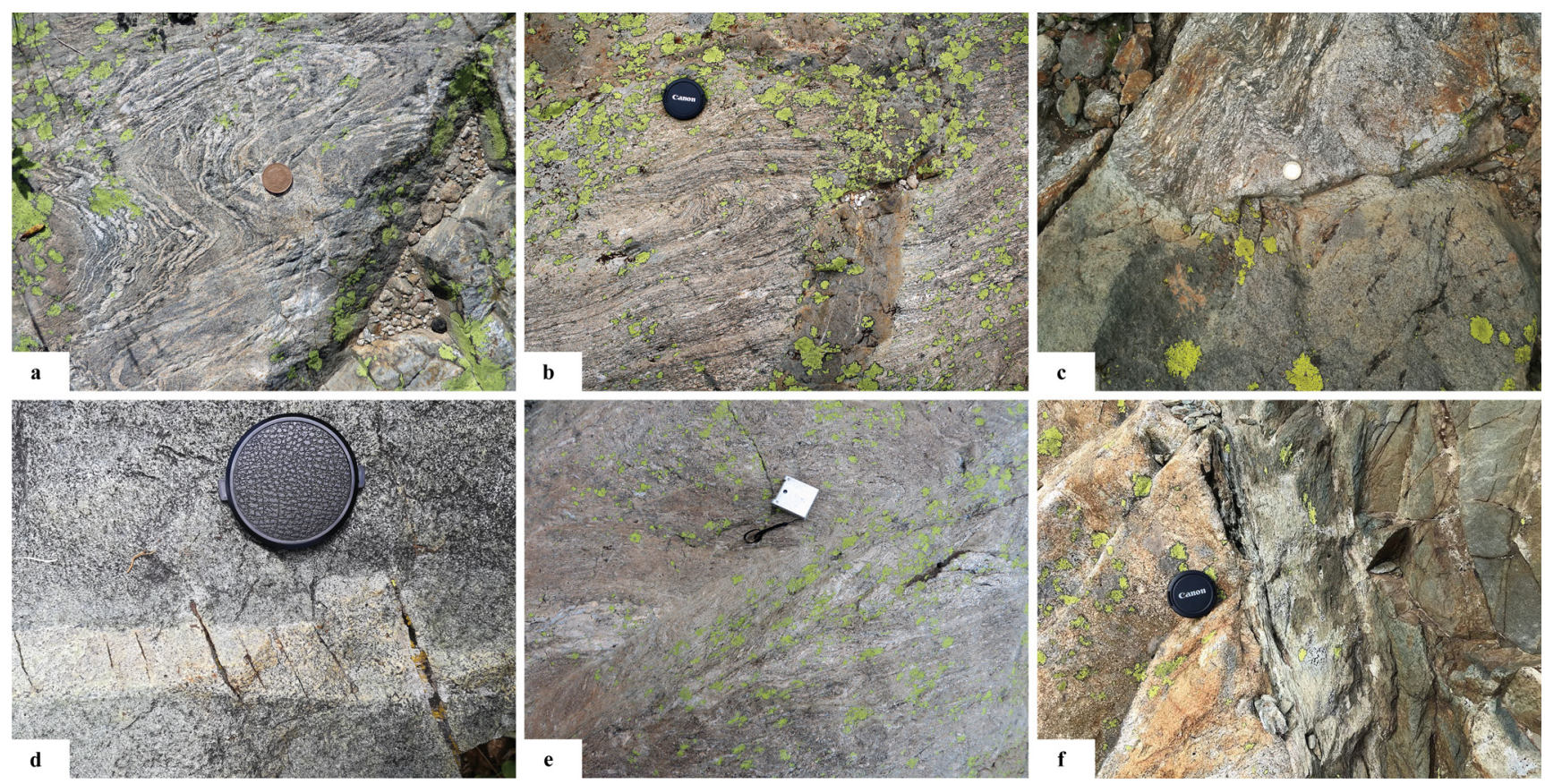

Fig. 4. Rock types and structures of Valscura: a: D3 folds bending D2 axial planes in migmatitic paragneisses (coin for scale); b: D2 fold hinges transposed into S2 foliation planes. Centimetre-thick lamprophyre with unfoliated chilled margins crosscut S2 (camera cap for scale); c: spessartite dyke with not foliated to slightly foliated chilled margin intersecting D3 folds in migmatitic paragneisses (coin for scale); d: leucoappinite vein into an appinite dyke; primary igneous minerals are locally replaced by aggregates of epidote and chlorite (yellowish in picture). Millimetre-sized D4 mineralised tensional veins are arranged along the leuco-appinite vein (camera cap for scale); e: D4 mylonitic foliations supported by chlorite and minor biotite interrupting and displacing to the right $\mathrm{S} 1+2$ foliation planes (compass for scale); f: spessartite dyke intruding fine-grained biotite-bearing granite. D4 foliation is pervasive along lamprophyre dyke walls (camera cap for scale).

migmatitic meta-granitoids. Relics of S1 and earlier formed veins of leucosome are preserved as hinges of tight to isoclinal D2 folds characterised by sub-horizontal and N- to NWtrending axes (Fig. 8). S1 and S2 axial plane foliation mainly dip to SW or to NE. S2 is locally affected by grain size reduction, as it occurs between Laghi Inferiori and Laghi Superiori di Valscura (Figs. 2 and $4 b$ ). Since newly formed cordierite-bearing leucosome veins crosscut D2 fold limbs and leucosomes fill saddle-reefs in D2 fold hinges, D2 developed under migmatitic conditions.

S2 was refolded during D3, which resulted in open to tight folds of metric wavelength (Fig. 4a), characterised by subvertical axes and by steep axial planes dipping NW or N (Fig. 8). A chlorite and phengite-bearing axial plane foliation (S3), dipping NW or SE (Fig. 8), is locally coupled with D3 folds. D3 folds are crosscut by granitoids and vertical to subvertical, NE-SW striking, lamprophyres (Figs. 4c and 8). Local deviation from the average striking likely reflects primary irregularities of the lamprophyre dyke walls (cf. Fig. 3).

Afterwards, sub-vertical NW-SE and minor E-W striking D4 mylonitic shear zones developed in the basement rocks (Fig. 8). NW-SE striking D4 mylonites are characterised by strike-slip dextral shearing, as suggested by S-C geometries, by sub-horizontal mineral lineation on shear planes, and by the offset of the lamprophyre dyke walls. The chilled margins were re-activated as shear surfaces during D4 (Fig. 4f) and stylolitic films, coupled with mineralised tension veins, developed. Field relationships, shear sense indicators, and supporting mineral assemblages allow correlating the D4 shear zones to the regional scale structures of Alpine age (Corsini et al., 2004; Baietto et al., 2009; Sanchez et al., 2011a; Leclère et al., 2014).

\subsection{Val du Haut Boréon site}

The dominant structure in the basement rocks of Val du Haut Boréon is the composite fabric $\mathrm{S} 1+2$, which results from the superposition of D2 tight to isoclinal folds on S1. Both D1 and D2 structures developed under migmatitic conditions, as suggested by leucosome in microlithons, and by leucosome veins crosscutting D2 hinges and limbs. D2 folds are generally isoclinal and fold limbs are parallel to SW-dipping D2 axial planes (Fig. 8). D2 stretching lineation in L to S-L synmigmatitic mylonites in migmatitic orthogneisses between Lac Guillié and Téte du Lacs Bessons, dips $40-70^{\circ}$ to SW. S2 is bent by D3 open folds of metric wavelength (Fig. 6), characterised by axes plunging to $\mathrm{SW}$ and axial surfaces dipping either to NW or to SE. D3 folds are intersected by white mica-bearing granite and aplite dykes.

All these rocks and structures are crosscut by sub-vertical NE-SW striking lamprophyres and by the E-W trending dyke of Lacs Bessons. The intrusive contacts between lamprophyres and country rocks are sharp and made angulated by synintrusive fracturing. Dykes are locally arranged in en-echelon systems, indicating emplacement contemporaneous to sinistral shearing (Fig. 6). Migmatites, granites and lamprophyres are, in turn, displaced by the NW-SE striking ductile to cataclastic 


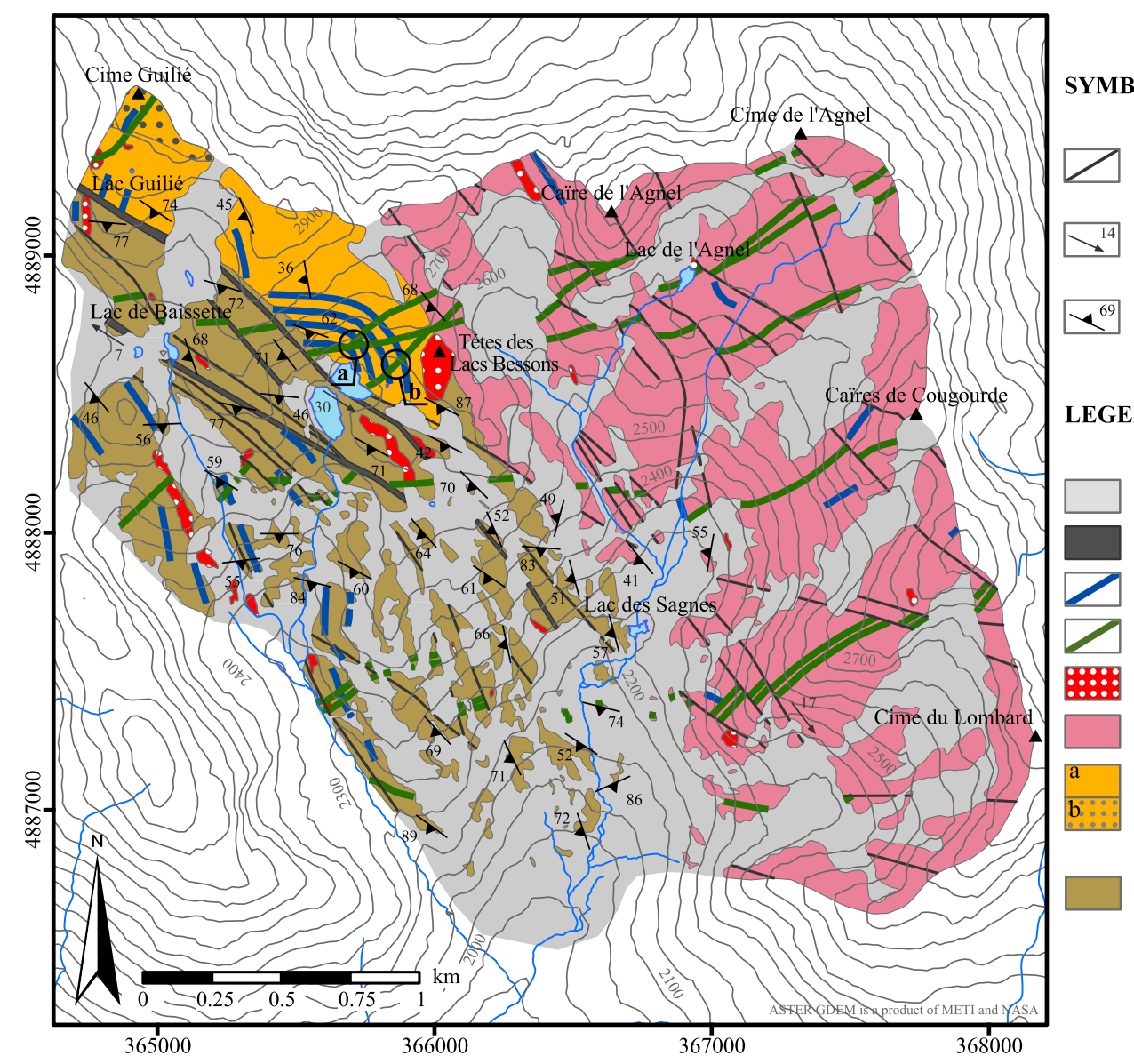

Trajectory of D4 mylonitic and cataclastic shear zones.

Trend and plunge of stretching lineations on D4 mylonitic foliation.

Dip direction and dip of syn-migmatitic $\mathrm{S} 1+2$.

LEGEND

Undifferentiated Quaternary covers.

D4 mylonitic shear zones.

Acidic dykes.

Lamprophyres.

Wm-granites.

Diatexites to anatexites.

a: foliated migmatitic orthogneisses (metatexites) and leuco-anatexites; b: migmatitic orthogneisses (metatexites) with porphyritic texture.

Migmatitic paragneisses (metatexites).

Fig. 5. Geo-structural map of Val du Haut Boréon ( $c f$. Fig. 1 to localise), upgraded after Blasi (1968). Projected coordinate system: WGS 84-UTM32N. Lacs Bessons stand at 4888500 N, 365647 E. Positions of outcrop scale form-surface maps are reported (cf. Fig. 6).

D4 shear zones, characterised by S-C surfaces and subhorizontal stretching lineations consistent with dextral sense of shear (Figs. 5 and 8). During D4, the intrusive contacts of lamprophyres were locally reactivated as sinistral shear planes, as testified by S-C foliations along the chilled margins (Fig. 7h).

\section{Whole rock geochemistry}

Lamprophyres are analysed for major and trace elements at SARM, "Centre de Recherche Petrographiques et Geochimiques" (CNRS, Vandoeuvre-les-Nancy, France) by ICPOES and ICP-MS, respectively. Information on the procedure, precision and accuracy is specified by Carignan et al. (2001). Analyses are carried out on 11 unfoliated samples from both the studied sites that do not appear significantly metamorphosed at meso- and micro-scale. Major and trace element compositions are reported in Table 1.

All the analysed samples share a calc-alkaline high-K character. Silica content of lamprophyres varies from 51 to $60 \%$ wt and the transition to the more silicic magmas is associated with decreasing of $\mathrm{MgO}, \mathrm{Fe}_{2} \mathrm{O}_{3}$ and $\mathrm{CaO}$, as well as increasing of $\mathrm{Al}_{2} \mathrm{O}_{3}$ and $\mathrm{K}_{2} \mathrm{O}$ amount. The MALI indexes plot either in the calc-alkalic or in the alkali-calcic fields (Fig. 9a); $\mathrm{A} / \mathrm{CNK}$ ratios from 0.66 to 1.15 correspond to metaluminous to slightly peraluminous melts (Fig. 9b). Lamprophyres are classified as magnesian in the Fe-number diagram of Frost et al. (2001) (Fig. 9c), whereas in the Mg-number-B classification scheme of Debon and Le Fort (1988) they plot in close proximity to the "critical line" that divides the "magnesian" from the "ferriferous" field.

The MORB-normalised spider diagram highlights humped patterns: the lamprophyres are markedly enriched in $\mathrm{Sr}, \mathrm{K}, \mathrm{Rb}$, $\mathrm{Ba}$, and $\mathrm{Th}$, whereas the Ti and $\mathrm{Y}$ contents plot close to MORB values (Fig. 9d). The concentrations of $\mathrm{Ni}$ and $\mathrm{Cr}$, which likely testify the mantle influence on the genesis of the melts, widely range from 83 to $6 \mathrm{ppm}$ and from 290 to $15 \mathrm{ppm}$, respectively, the content of $\mathrm{V}$ decreases from 332 to $68 \mathrm{ppm}$ with the increase of the silica content from 50.96 to $56.17 \%$ wt. The geochemical signatures of the Argentera-Mercantour lamprophyres are thus consistent with crustal contamination of mantle-derived magmas.

\section{Lamprophyres microstructures}

\subsection{Igneous microstructures}

Lamprophyres are mainly constituted by igneous amphibole and plagioclase. AmpI1 is brown, euhedral to subhedral, and commonly twinned (mineral abbreviations are from 


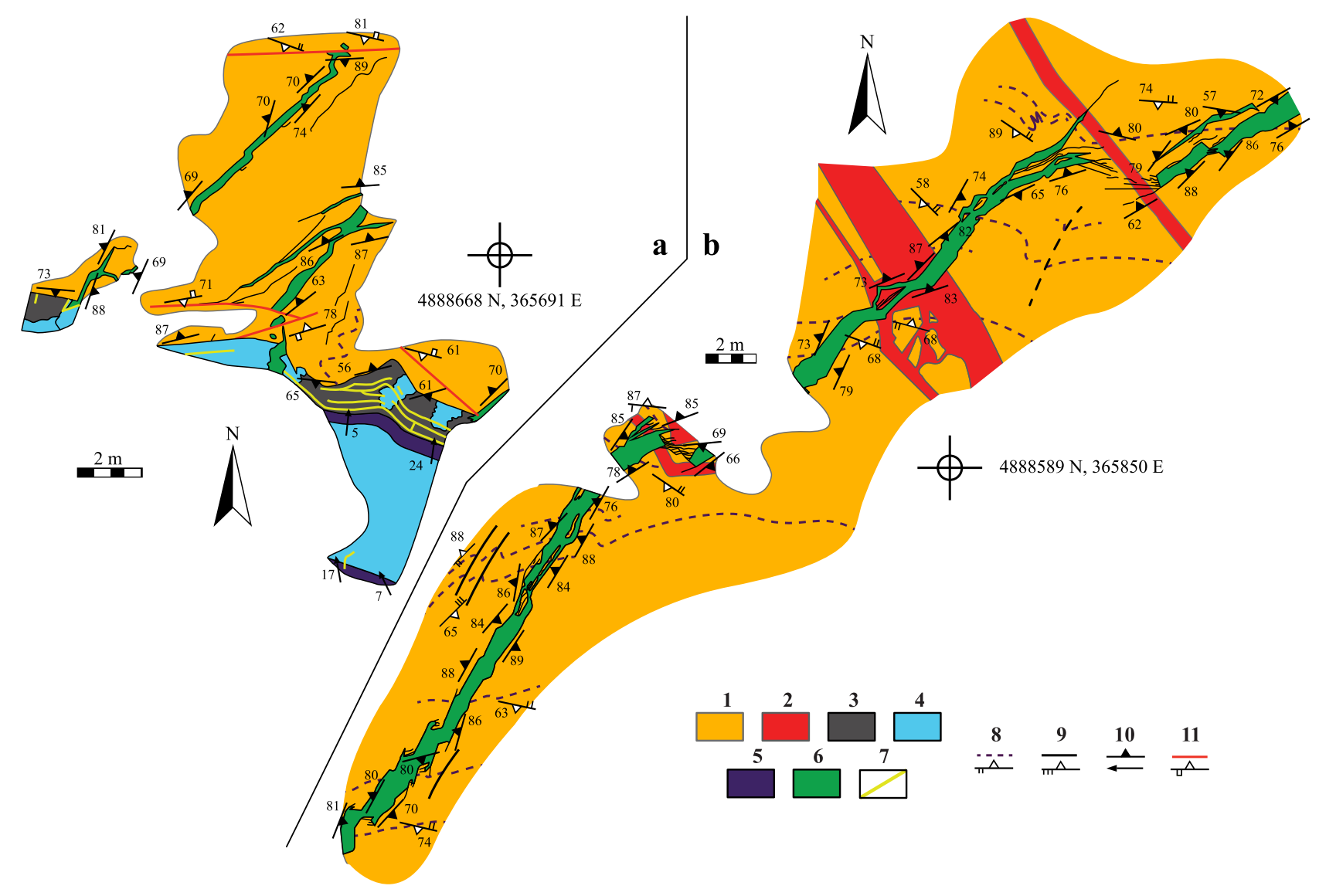

Fig. 6. Form-surface maps of selected outcrops in Val du Haut Boréon mapped at 1/100 scale (locations in Fig 5). 5. Legend: 1: leuco-anatexites; 2: white mica-bearing granitic dykes; 3: melanocratic spessartites; 4: mingled appinites and leuco-appinites; 5: comb layered appinites; 6: spessartites; 7: leucocratic veins; 8: trajectory, dip direction, and dip of S1+2 foliation; 9: dip direction and dip of D3 axial plane; 10: dip direction and dip of lamprophyre dyke walls, trend and plunge of amphibole phenocrysts in comb layers; 11: trajectory, dip direction and dip of D4 mylonitic to stylolitic foliation. Scale bars, north arrows, and geo-referenced points are assigned to each outcrop (projected coordinate system: WGS 84-UTM 32N).

Whitney and Evans, 2010). It displays oscillatory compositional zoning (Fig. 10a) and, only in few cases, preserves dark brown cores with corroded boundaries. PII1 is in subhedral crystals or small laths, usually forming simple or polysynthetic twins. Glomeroporphyric aggregates of clinopyroxene occur in the spessartites from Val du Haut Boréon (Fig. 10b), whereas aggregates of chlorite, titanite, and biotite entirely replaced euhedral crystals likely of igneous biotite or clinopyroxene in both aphanitic and phaneritic rocks. Accessories apatite, magnetite, and ilmenite are included within AmpI1 and PII1 in the phaneritic rock types (Fig. 10a), or lie within the groundmass in the spessartites.

In appinites and leuco-appinites, up to centimetre-sized crystals of AmpI1 are randomly oriented and associated with smaller subhedral to interstitial grains of PII1, KfsI1, and rare QzI1.Mingling structures between appinites and leuco-appinites are highlighted by modal variations of AmpI1 and PII1.

Spessartites are highly heterogeneous in term of textures: sub-millimetric phenocrysts of AmpI1 typically occur within a microcrystalline groundmass, or together with twinned laths of PII1. In few cases, phenocrysts of AmpI1 are partly to entirely enclosed in up to centimetre-sized crystals of PII1, conveying a sub-ophitic to ophitic textures. Strain-free phenocrysts of AmpI1 and laths of PII1 with SPO support the magmatic foliation in spessartites. Approaching the chilled margins, the SPO of crystals supporting the magmatic foliation is progressively more pervasive and homogeneous.

In melanocratic spessartites, irregular-shaped amphibolerich domains of centimetre size are enclosed in a more leucocratic groundmass. Two types of amphibole-rich domains are recognised, both with anhedral to subhedral interstitial PII1 crystals: in the former, crystals of AmpI1 are dark-brown and highly prolate, whereas, in the latter, AmpI1 occurs in brown stocky grains. AmpIl crystals in comb layered appinites display a seriate crystal size distribution: centimetre-sized phenocrysts of AmpI1 with interstitial PII1 are iso-oriented and, locally, in fan-shaped aggregates, whereas millimetre- and sub-millimetre-sized AmpI1 crystals are randomly oriented and completely to partially included in PIII.

Vesicles, which commonly occur in spessartites and melanocratic spessartites, are tangentially bounded by undeformed crystals of AmpI1 (Fig. 10c) and are locally filled either by PII1 and AmpI1 radially oriented, by hydrothermal 

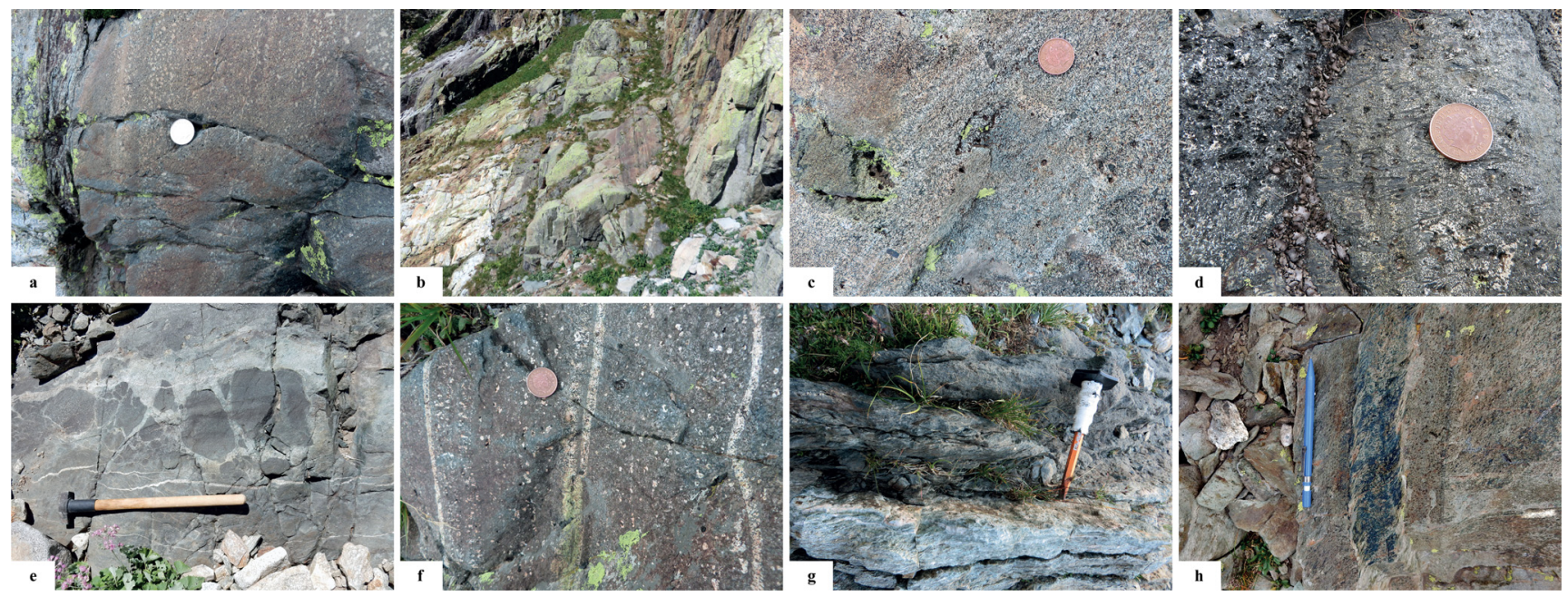

Fig. 7. Rock types and structures of Val du Haut Boréon: a: foliated chilled margin and vesicle-rich layers running parallel to melanocratic appinite dyke walls (coin for scale); b: the 10-metre-thick mafic dyke of Lacs Bessons and its symmetrical structure; c: appinite enclaves mingled in leuco-appinite at core of the main mafic dykes of Lacs Bessons. Appinite and leuco-appinite may be pervasively replaced by granoblastic aggregates of epidote and chlorite, i.e. at the left margin (coin for scale); d: comb layered appinite with phenocrysts of amphibole of centimetresize. Amphibole phenocrysts are perpendicularly oriented with respect to the dyke walls. The fine-grained matrix is locally replaced by greenish aggregates of epidote and chlorite (coin for scale); e: disrupted fragments of melanocratic spessartite into appinite and leuco-appinite groundmass; leucocratic veins crosscut the edges of the fragments (hammer for scale); f: leucocratic veins within melanocratic spessartite characterised by layers of vesicles; at bottom, the central leucocratic vein is widely replaced by epidote and chlorite (coin for scale); g: mylonitic shear zone of Alpine age crosscutting the dyke of Lacs Bessons. The mafic dyke is affected by a composite foliation where $\mathrm{S}$ and $\mathrm{C}$ surfaces are mainly supported by biotite and chlorite; S-C structure geometry are consistent with the sense of displacement of the dyke (cf. Fig. 5) (chisel for scale); h: S-C structures suggesting sinistral sense of shear along the wall of a spessartite dyke (pencil for scale).
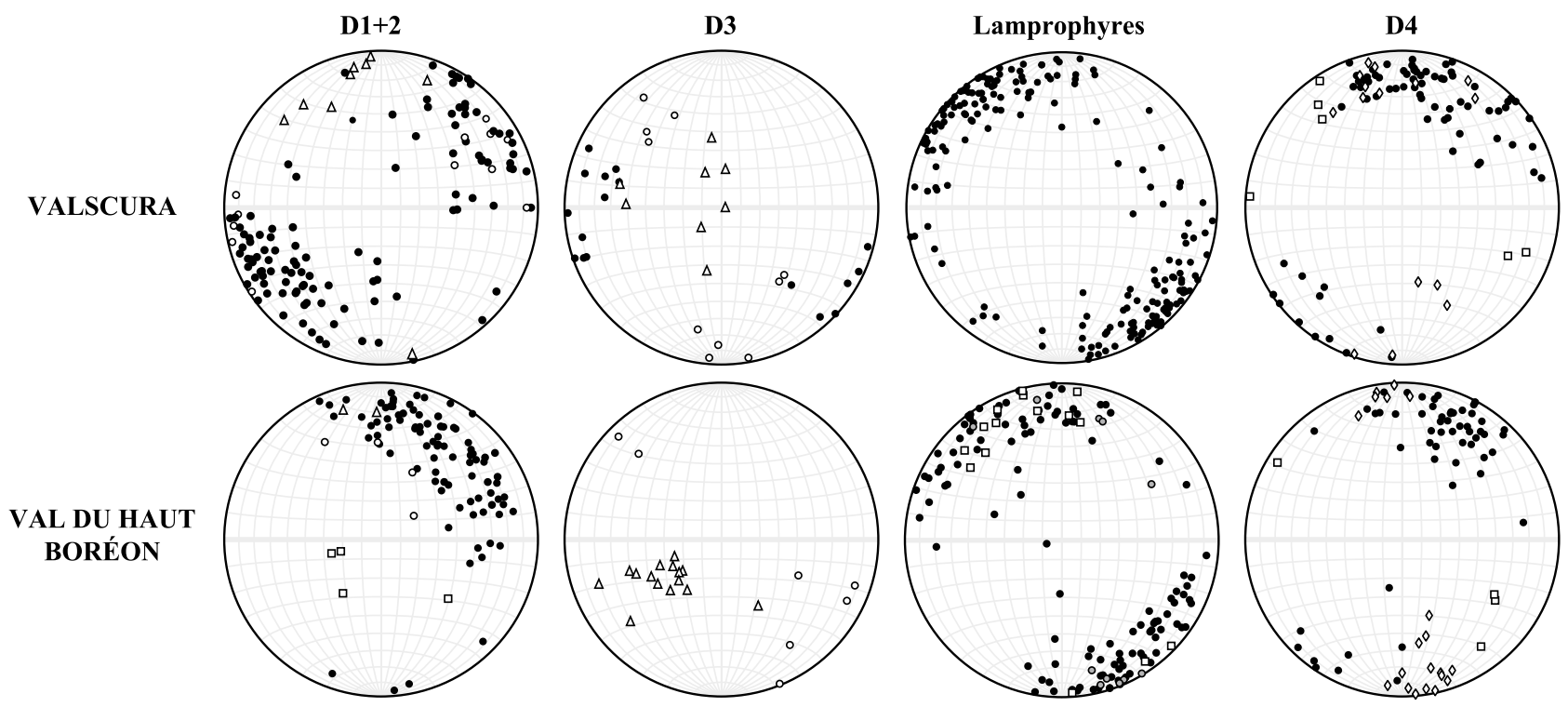

Fig. 8. Stereographic projections of structural data (equal-area, lower-hemisphere), divided by relative chronology of deformative and intrusive events. Legend: D1+2: circles = poles of $\mathrm{S} 1+2(111$ data from Valscura, 89 data from Val du Haut Boréon $)$; open squares = mineral lineations on $\mathrm{S} 1+2$ (4 data from Val du Haut Boréon); open circles = poles of axial planes of D2 folds (12 data from Valscura, 4 data from Val du Haut Boréon); open triangles $=$ axes of D2 folds (9 data from Valscura, 2 data from Val du Haut Boréon). D3: circles = poles of S3 (17 data from Valscura); open circles $=$ poles of axial planes of D3 folds (10 data from Valscura, 7 data from Val du Haut Boréon $)$; open triangles $=$ axes of D3 folds $(8$ data from Valscura, 15 data from Val du Haut Boréon). Lamprophyres: circles=poles of dyke walls (195 data from Valscura, 116 data from Val du Haut Boréon); grey circles = poles of leucocratic veins (11 data from Val du Haut Boréon); open squares = amphibole-supported lineations in comb layers (15 data from Val du Haut Boréon). D4: circles = poles of mylonitic foliations (76 data from Valscura, 56 data from Val du Haut Boréon); open squares = stretching lineations on D4 shear zones (6 data from Valscura, 4 data from Val du Haut Boréon); open diamonds = poles of D4 stylolitic and mylonitic foliations along lamprophyre dyke walls (15 data from Valscura; 19 data from Val du Haut Boréon). 
Table 1. Major (wt.\%) and trace (ppm) element concentrations of lamprophyres from Valscura and Val du Haut Boréon. Abbreviations: sp: spessartite; mel sp: melanocratic spessartite; c-l ap: comb layered appinite; ap: appinite; leuco ap: leuco-appinite.

\begin{tabular}{|c|c|c|c|c|c|c|c|c|c|c|c|}
\hline \multicolumn{10}{|c|}{ Val du Haut Boréon } & \multicolumn{2}{|c|}{ Valscura } \\
\hline $\mathrm{TiO} 2$ & 1.58 & 1.38 & 0.83 & 1.37 & 1.13 & 0.93 & 0.73 & 1.19 & 0.80 & 1.18 & 1.12 \\
\hline $\mathrm{Al}_{2} \mathrm{O}_{3}$ & 15.28 & 16.31 & 17.53 & 15.93 & 14.73 & 20.10 & 17.65 & 14.41 & 21.08 & 13.22 & 15.97 \\
\hline $\mathrm{CaO}$ & 4.28 & 3.98 & 5.42 & 7.11 & 7.12 & 4.95 & 4.94 & 7.25 & 5.12 & 8.41 & 7.59 \\
\hline $\mathrm{Na}_{2} \mathrm{O}$ & 4.13 & 2.75 & 3.97 & 4.15 & 3.98 & 4.31 & 2.89 & 4.08 & 4.13 & 1.98 & 3.08 \\
\hline $\mathrm{K}_{2} \mathrm{O}$ & 1.82 & 2.23 & 2.22 & 2.26 & 1.61 & 1.75 & 2.19 & 1.72 & 2.05 & 1.26 & 2.11 \\
\hline $\mathrm{P}_{2} \mathrm{O}_{5}$ & 0.72 & 0.38 & 0.32 & 0.57 & 0.67 & 0.43 & 0.21 & 0.95 & 0.44 & 0.96 & 0.74 \\
\hline $\mathrm{MnO}$ & 0.15 & 0.12 & 0.10 & 0.11 & 0.10 & 0.13 & 0.08 & 0.13 & 0.11 & 0.15 & 0.11 \\
\hline $\mathrm{Rb}$ & 100.2 & 71.8 & 76.9 & 75.5 & 65.5 & 84.4 & 81.4 & 58.4 & 85.7 & 54.3 & 75.2 \\
\hline $\mathrm{Ba}$ & 258 & 398.5 & 1183 & 1078 & 875.8 & 1769 & 1027 & 835.3 & 1889 & 628 & 1075 \\
\hline $\mathrm{Sr}$ & 269 & 373 & 772 & 528 & 479 & 1017 & 436 & 457 & 1048 & 320 & 494 \\
\hline $\mathrm{Pb}$ & 21.6 & 22.8 & 26.9 & 25.2 & 24.2 & 35.0 & 8.0 & 23.6 & 35.3 & 13.8 & 26.1 \\
\hline $\mathrm{Th}$ & 6.6 & 5.5 & 5.4 & 6.2 & 6.6 & 5.3 & 4.2 & 4.3 & 5.2 & 4.5 & 5.6 \\
\hline $\mathrm{Zr}$ & 274 & 182 & 193 & 234 & 230 & 357 & 254 & 227 & 381 & 117 & 238 \\
\hline $\mathrm{Ta}$ & 6.8 & 3.3 & 3.6 & 4.3 & 4.1 & 4.4 & 5.2 & 3.9 & 3.9 & 3.7 & 5.9 \\
\hline $\mathrm{Y}$ & 43 & 31 & 20 & 34 & 38 & 17 & 15 & 38 & 15 & 47 & 32 \\
\hline $\mathrm{Nb}$ & 16 & 10 & 12 & 10 & 12 & 10 & 10 & 13 & 10 & 14 & 10 \\
\hline $\mathrm{Cr}$ & 17 & 20 & 15 & 191 & 94 & 17 & 290 & 92 & 17 & 66 & 185 \\
\hline $\mathrm{Ni}$ & 33 & 83 & 7 & 64 & 27 & 6 & 26 & 28 & 6 & 14 & 70 \\
\hline
\end{tabular}

mineral assemblages, or by twinned crystals of calcite. Along the chilled margins, small phenocrysts of AmpI1 are recognisable within the cryptocrystalline groundmass (Fig. 10d). The igneous mineral assemblages filling leucocratic veins comprises AmpI1, PII1, KfsI1, and minor QzI1.

Dark-green AmpI2 rims AmpI1 in Valscura lamprophyres (Fig. 10e) and partially replaces AmpI1 in and around the leucocratic veins in Val du Huat Boréon (Fig. 10f). AmpI2 is interpreted as late-magmatic phase since it is replaced by hydrothermal mineral assemblages (M1, described below).

\subsection{Subsolidus microstructures}

Microstructures developed under subsolidus conditions and supporting mineral assemblages are similar in both the investigated areas. However, in Val du Boréon, syn-D4 mineral assemblages are significantly developed only in intermediate to high strain domains.

M1 is the earliest post-magmatic mineral assemblage retained by the lamprophyres, which comprises AbM1+
$\mathrm{ActM} 1+\mathrm{ChlM} 1+\mathrm{EpM} 1+\mathrm{KfsM} 1+\mathrm{TtnM} 1 \pm \mathrm{BtM} 1 \pm$

CalM1 \pm QzM1 in polygonal aggregates with rational grain boundaries and without SPO (Fig. 11a). Up to millimeter-sized randomly-oriented epidote grains are diagnostic for M1. Rare aggregates of ZoM1 may occupy the same microstructural domains of EpM1, as observed in few samples from Val du Haut Boréon. OpqM1, hematite and pyrite, locally occur. AmpI1 and AmpI2 are partially to totally replaced by aggregates of anhedral and un-twinned AbM1, colourless ActM1, ChlM1, EpM1, TtnM1, and rare QzM1 (Figs. 10e and 11b-11d); a similar mineral assemblage, but without ActM1, replaced PlI1. BtM1 rims KfsI1.

M2 mineral assemblages support stylolitic and mylonitic D4 foliations in lamprophyres (Figs. 11c-11f). Igneous phenocrysts and aggregates of EpM1 are wrapped by D4 mylonitic foliation marked by SPO of $\mathrm{AbM} 2+\mathrm{BtM} 2+$ $\mathrm{ChlM} 2+\mathrm{TtnM} 2+\mathrm{PhM} 2 \pm \mathrm{ActM} 2 \pm \mathrm{EpM} 2 \pm \mathrm{OpqM} 2 \pm \mathrm{QzM} 2$ (Figs. 11d and 11e), and are partially dissolved at strain caps or along stylolitic films mainly supported by microgranular aggregates of TtnM2 (Figs. 11c, 11e and 11f). Pale-green 

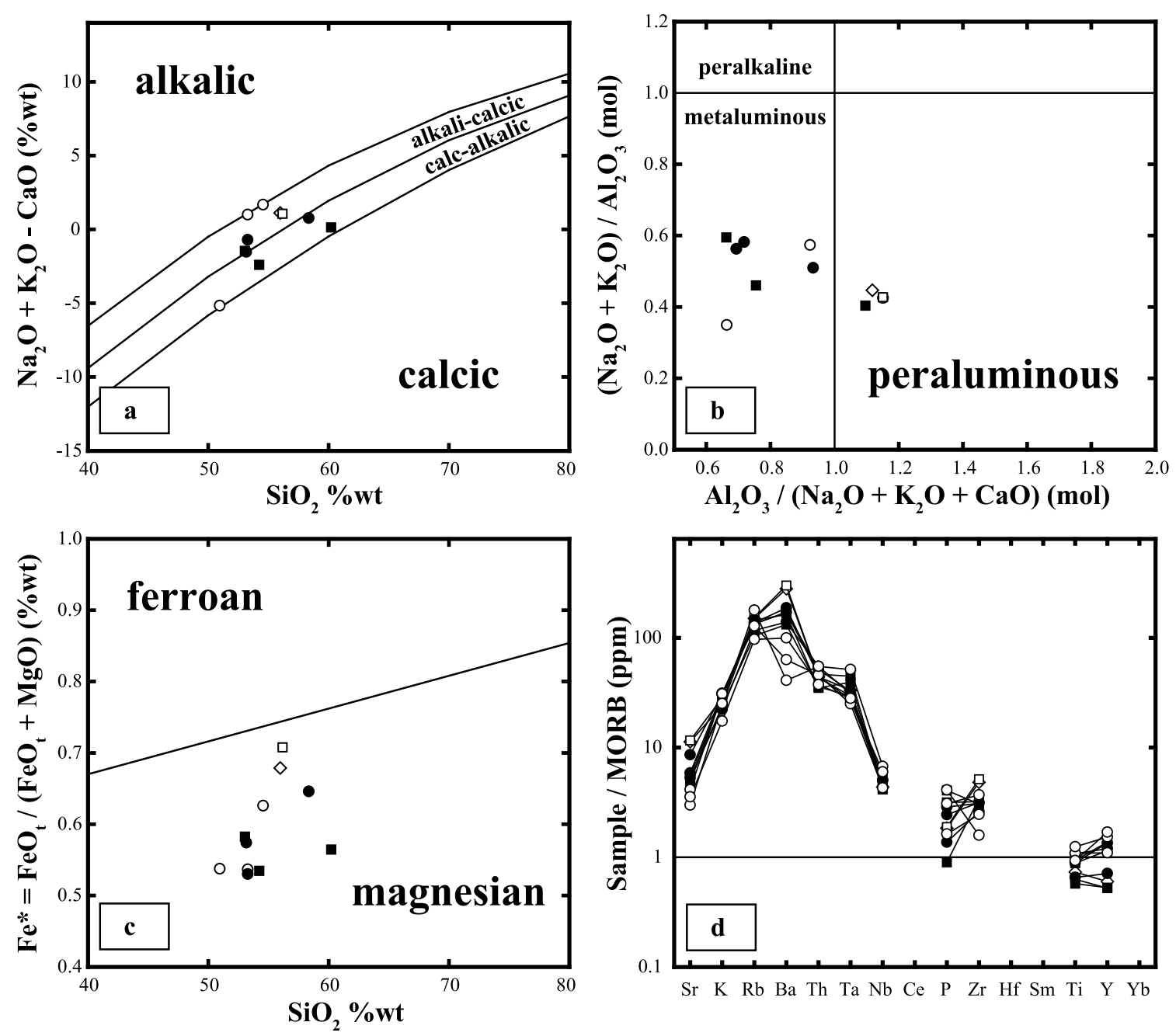

Fig. 9. Geochemical classification diagrams of igneous rocks (Frost et al., 2001): A: modified alkali-lime index (MALI); B: Al saturation index (ASI); C: Fe-number vs. $\mathrm{SiO}_{2} \%$ wt. D: multi-element patterns normalised to MORB values (Sun and McDonough, 1989). Legend: square: appinite; open square: leuco-appinite; circle: melanocratic spessartite; open circle: spessartite; open diamond: comb layered appinite.

ActM2 fills pressure shadows and boudin necks of AmpI1 porphyroclasts (Figs. 11d and 11f). Newly formed grains of ActM2 rarely mark the D4 mylonitic foliation. KfsM2 exclusively fills tensional veins at dyke margins, where is associated with AbM2 + ActM2 + BtM2 + ChlM2 (Fig. 11b). In low-strain domains, AmpI1 phenocrysts, partially to totally overgrown by M1 assemblages, are rimmed by discontinuous coronae of ActM2. M2 mineral assemblages, which support D4 structures in lamprophyres, are consistent with the transition between greenschist and amphibolite facies conditions (Maruyama et al., 1982; Maruyama et al., 1983; Spear, 1993).

\section{Discussion}

Structural and metamorphic relationships between lamprophyres, granitoids, and migmatites allow an accurate discrimination between superposed Variscan and Alpine tectono-metamorphic stages in the crystalline basement of the Argentera-Mercantour Massif. During D2, which was coeval with the Variscan migmatisation, deformation was highly heterogeneous, as indicated by D2 mylonites through domains where the dominant fabric is the folded $\mathrm{S} 1$ foliation. Late-Variscan D3 event is responsible for folds, subsequently crosscut by acidic dykes and pockets, and by younger NE-SW striking lamprophyres.

The Argentera-Mercantour lamprophyres are spessartites and appinites, formed by AmpI1, PII1, and minor KfsI1. Igneous clinopyroxene is observed in few spessartite dykes, whereas QzI1 is rare in phaneritic rock types. Rims of latemagmatic AmpI2 may occur, in particular at or near sets of late leucocratic veins. Mingling and magmatic breccia textures are common in spessartites, appinites, and leuco-appinites, which are locally divided by comb layers. These structures point out that the dykes have collected compositionally heterogeneous magmas during their ascent. 

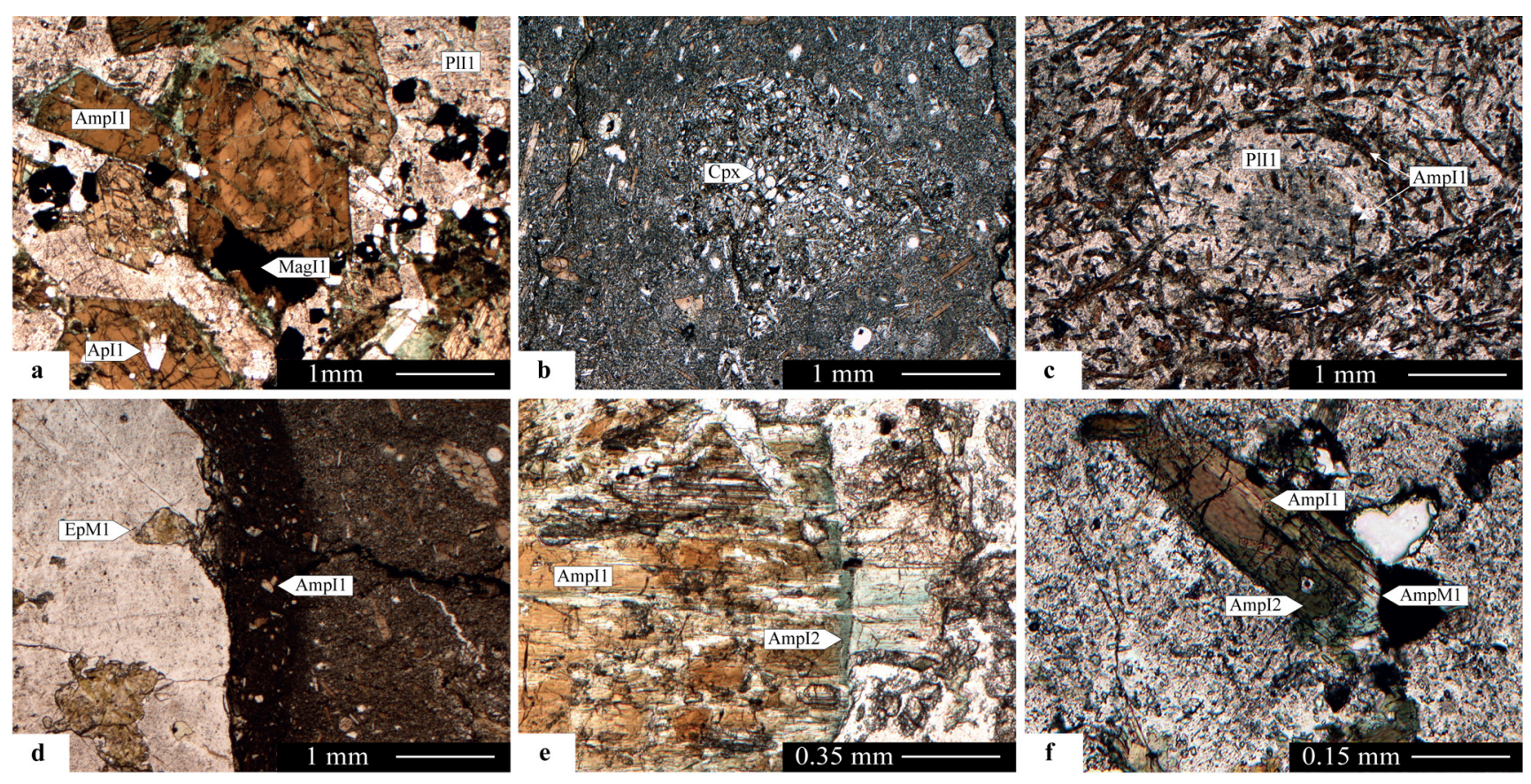

Fig. 10. Igneous mineral assemblages and microstructures characterising the lamprophyres of Valscura and Val du Haut Boréon: a: euhedral to subhedral crystals of brown AmpI1 and PII1 partially including ApI1 and MgtI1 in appinite, Val du Haut Boréon. AmpI1 displays oscillatory compositional zoning; b: aggregates of sub-millimetre sized igneous clinopyroxene in spessartite, Val du Haut Boréon; c: vesicles filled by PII1 and AmpI1 in melanocratic spessartite, Val du Haut Boréon. Phenocrysts of AmpI1 are tangentially oriented around the vescicle; d: chilled margin marking the intrusive contact between a spessartite dyke and the host migmatite in Val du Haut Boréon. Micro-phenocrysts of AmpI1 are within the chilled margin domain; aggregates of EpM1 (see next paragraph) developed in both the rock types close to the intrusive contact; e: zoned crystal of brown AmpI1 rimmed by dark-green AmpI2 in appinite, Valscura; f: leucocratic vein where a phenocryst of AmpI1 is firstly overgrown by dark-green AmpI2 and then by colourless ActM1 (see next paragraph), Val du Haut Boréon. All pictures are taken by plane polarised light.

Chilled margins and vesicles, the latter interpreted as resulting from degassing (Vernon, 2018), suggest that the Argentera-Mercantour Massif had been already exhumed at shallow depths before the emplacement of the lamprophyres. Furthermore, brittle structures accomodated their emplacement. M1 assemblages (AbM1 + ActM1 + ChlM1 + EpM1 + $\mathrm{KfsM} 1+\mathrm{TtnM} 1 \pm \mathrm{BtM} 1 \pm \mathrm{CalM} 1 \pm \mathrm{QzM} 1 \pm \mathrm{OpqM} 1 \pm$

QzM1), which exclusively developed in the lamprophyres and along their margins, reflect localised hydrothermal circulation that took place during the latest emplacement stages, unrelated with the Alpine tectono-metamorphic evolution.

Lamprophyres are crosscut by dextral shear zones of Alpine ages (D4), striking from E-W to NW-SE, the latter of which characterised by sub-horizontal mineral lineations. M2 assemblages $\left(\mathrm{AbM} 2+\mathrm{BtM} 2+\mathrm{ChlM} 2+\mathrm{TtnM} 2+\mathrm{PhM}_{2} \pm\right.$ $\mathrm{ActM} 2 \pm \mathrm{EpM} 2 \pm \mathrm{KfsM} 2 \pm \mathrm{OpqM} 2 \pm \mathrm{QzM} 2)$ support $\mathrm{D} 4$ foliation in lamprophyres, fill D4 tensional veins at dyke walls, and rim both igneous and M1 assemblages in low strain domains. Therefore, the lamprophyres of the ArgenteraMercantour Massif retain Alpine metamorphic conditions compatible with the transition between the greenschist and amphibolite facies. Since M2 mineral assemblages are similar in Valscura and Val du Haut Boréon, similar Alpine metamorphic conditions are assumed for the two tectonic slices divided by the Fremamorta Shear Zone (FMZ in Fig. 1).
Furthermore, no changes in dyke attitudes between the two areas imply that only minor relative rotation has affected these two slices since the lamprophyre emplacement up to the present day, despite of the interposition of the FSZ.

In the Argentera-Mercantour Massif, rapid exhumation of the thickened Variscan crust in late-collisional setting triggered decompression melting at around $323 \pm 12 \mathrm{Ma}$ (Rubatto et al., 2001; Ferrando et al., 2008), which culminated with the surface exposure of the lower crust from late Carboniferous times (Faure-Muret 1955; Malaroda et al., 1970; Bortolami et al., 1974). It occurred after the slab break-off (Rubatto et al., 2001; von Raumer et al., 2014) and concurrently with the emplacement of the Central Granite (Boucarut, 1967; Ferrara and Malaroda 1969; Corsini et al., 2004). After tens of million years of migmatisation and successive emplacement of early Permian peraluminous granitoids in the retrogressed and exhumed migmatites, texturally heterogeneous lamprophyres, resulting from crustal contamination of mantle-derived magmas, emplaced at shallow crustal levels. A PermianTriassic age for the Argentera-Mercantour lamprophyres is suitable for the following reasons: i) the lamprophyres only intruded into Variscan migmatites and early Permian granitoids, but not into the Mesozoic to Tertiary sedimentary sequences (Faure-Muret 1955; Malaroda et al., 1970); ii) the lamprophyres record a prograde metamorphism, reaching 

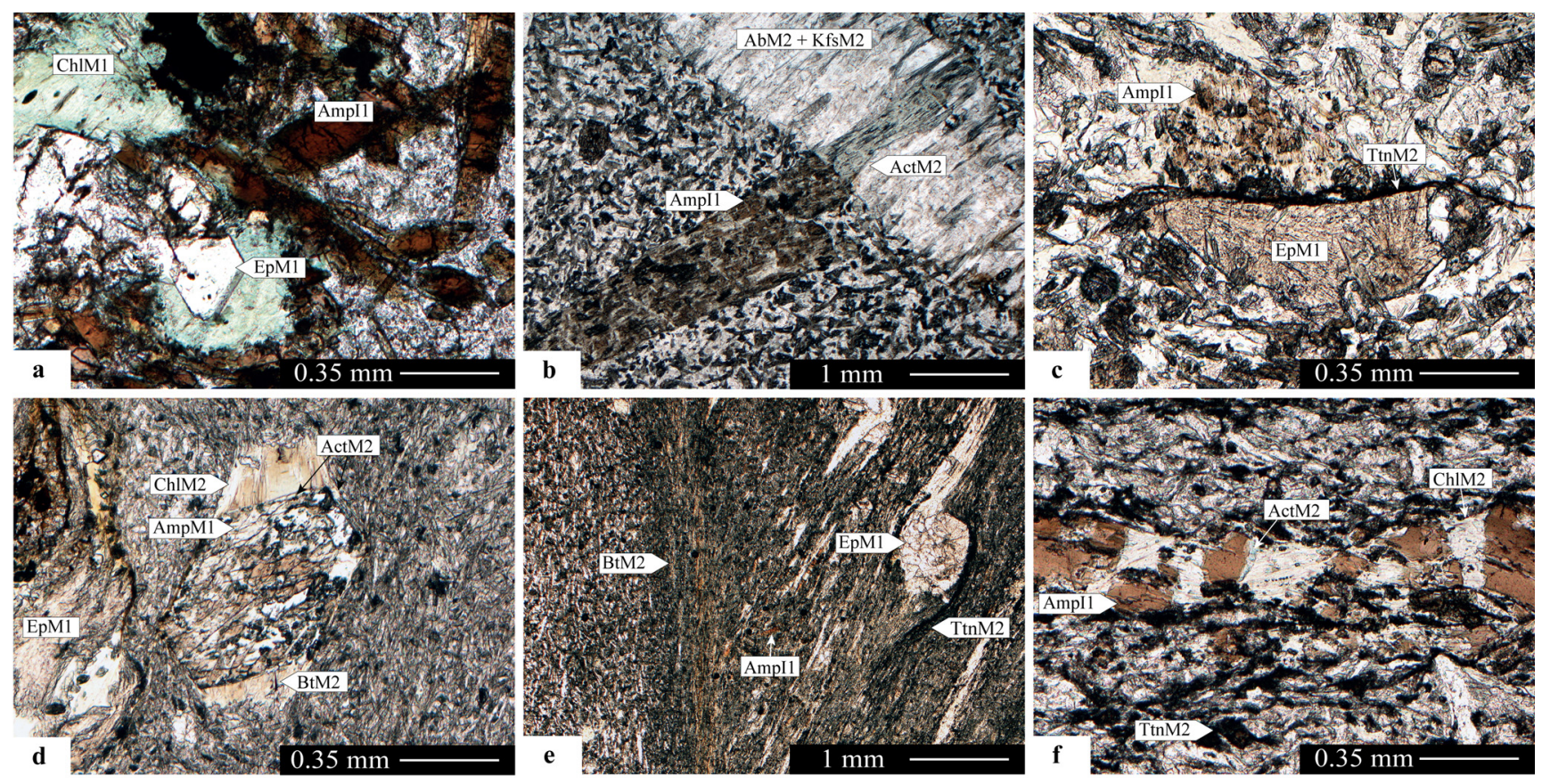

Fig. 11. Metamorphic mineral assemblages and microstructures characterising the lamprophyres of Valscura and Val du Haut Boréon: a: granoblastic aggregates of EpM1 + ChlM1 pervasively overgrew igneous crystals in melanocratic spessartite, Val du Haut Boréon; b: mineralised tensional vein filled by elongated crystals of AbM2, ActM2, and KfsM2 in spessartite, Valscura. ActM2 grew in continuity with truncated phenocrysts of AmpI1 already replaced by M1 mineral assemblages; c: stylolitic foliation, supported by fine-grained crystals of TtnM2, which define the contact between a phenocryst of AmpI1 partially replaced by M1 mineral assemblages (at top) and an aggregate of EpM1 (at bottom) in spessartite, Valscura. Stylolitic foliation is cinematically compatible with the opening of mineralised tensional veins in Figure 11c; d: spessartite containing a porphyroclast of AmpI1 largely pseudomorphosed by M1 mineral assemblages and wrapped by D4 foliation, Valscura; pressure shadow domains are filled by BtM2, ChlM2 and minor ActM2 at the edges of the AmpI1 porphyroclast; e: aggregates of EpM1 and small phenocrysts of AmpI1 wrapped by D4 foliation in a heterogeneously deformed spessartite dyke, Val du Haut Boréon. Trails of TtnM2 and laminae of BtM2 and ChlM2 are the mineralogical support of D4 S-C surfaces; f: Micro-boudins of AmpI1 in a foliated spessartite dyke, Val du Haut Boréon. Boudin necks are filled by ActM2 and ChlM2; the foliation is mostly defined by trails of finegrained TtnM2, and minor BtM2 and ChlM2. All pictures are taken by plane polarised light.

metamorphic conditions at the transition between the greenschist and amphibolite facies during the Alpine deformation. Furthermore, dacites and basalts are reported in the Permian siliciclastic sequences (Faure-Muret, 1955; Malaroda et al., 1970; Romain and Vernet, 1978).

The tectonic setting accountable for the Permian-Triassic magmatism in the southern Variscan belt area is controversial. Both the calc-alkaline and the subsequent alkaline cycles, comprising transitional to tholeiitic mafic rocks, have been intepreted either as a result of Variscan collapse, or crustal delamination, or post-orogenic extension (e.g. Lardeaux and Spalla, 1991; Bussy et al., 2000; Cannic et al., 2002; Cocherie et al., 2005; Bussien et al., 2008; Buzzi and Gaggero, 2008; Dallagiovanna et al., 2009; Spalla et al., 2014; Rossi et al., 2015). Numerical models performed to explore the transition from Variscan convergence to Permian-Triassic extension indicate that forced extension (at least $2 \mathrm{~cm} / \mathrm{yr}$ ) is necessary to produce successive pulses of mantle-derived magma in Permian-Triassic times: such a magmatic activity could not result from the gravitational evolution characterising the end of the Variscan subduction-collision (e.g. Marotta et al., 2009; Marotta et al., 2018; Roda et al., 2018). Taking into accounts these model predictions, the Argentera-Mercantour lamprophyres are more easily interpreted as magmatic records of the Permian-Triassic lithospheric thinning, announcing the Jurassic rifting on the European margin, instead of the igneous witness of the late-Variscan collapse.

\section{Conclusion}

The multiscale structural analysis carried out in the southeastern portion of the Argentera-Mercantour Massif highlights the following significant steps of its geodynamic evolution, from Variscan to Alpine times:

- texturally heterogeneous lamprophyres, magnesian, calcalkalic to alkali-calcic and metaluminous in composition, emplaced at shallow crustal levels crosscutting three generations of superposed Variscan structures in the migmatitic complex and early Permian granitoids;

- lamprophyres were places of hydrothermal circulation immediately after their intrusion;

- mineral assemblages supporting the strike-slip mylonitic shear zones of Alpine ages are consistent with the transition between the greenschist and amphibolite facies. 
Syn-intrusive structures and metamorphic evolution are thus reasonably consistent with the lamprophyres of the Argentera-Mercantour Massif interpreted as evidence of Permian-Triassic lithospheric thinning in the External Crystalline Massifs of Western Alps.

Acknowledgement. The authors acknowledge funding by University of Milano: Linea 2, Azione A-fondi giovani ricercatori "Analisi strutturale delle catene collisionali" (PSR2018_DZANONI). Achille Blasi has driven our attention to the dykes of val du Haut Boréon, making available to G.G. a wealth of his samples and unpublished 1/10 000 maps from the sixties; inclusion of data from master theses by Luigi Cinquegrani and Valentina Montani is gratefully acknowledged. Curzio Malinverno prepared quality thin sections. Part of this work supported compilation of the candidacy Dossier on the area "Alpes de la Méditerranée" as UNESCO world heritage site. Facilities for fieldwork logistics were provided by "GECT Alpi Marittime-Mercantour". For these reasons, the paper is framed in the MIUR project "Dipartimenti di Eccellenza 2017-Le geoscienze per la società: risorse e loro evoluzione" (work-package 4, task 3). Two anonymous reviewer are thanked for constructive comments.

\section{References}

Aicard P, Autran A, Gérard J, Lougnon J. 1968. Sur l'âge tertiaire syntectonique et synmétamorphique alpin du gisement plombozincifère de Valauria (commune de Tende, Alpes Maritimes). Bull BRGM 1: 5-14.

Attal M. 2000. Étude tectonique et thermodynamique du tégument permo-triasique du flanc méridional du Massif de l'Argentera. Géol Alp 76: 167-170.

Atzori P, Cirrincione R, Del Moro A, Mazzoleni P. 2000. Petrogenesis of late Hercynian calc-alkaline dykes of mid-eastern Sardinia: Petrographical and geochemical data constraining hybridization process. Eur J Mineral 12: 1261-1282. DOI: 10.1127/0935-1221/ 2000/0012-1261.

Baietto A, Perello P, Cadoppi P, Martinotti G. 2009. Alpine tectonic evolution and thermal water circulations of the Argentera Massif (South-Western Alps). Swiss J Geosci 102(2): 223-245. DOI: 10.1007/s00015-009-1313-5.

Baletti L, Zanoni D, Spalla MI, Gosso G. 2012. Structural and petrographic map of the Sassa gabbro complex (Dent Blanche nappe, Austroalpine tectonic system, Western Alps, Italy). J Maps 8: 413-430. DOI: 10.1080/17445647.2012.745678.

Banzet G. 1987. Interaction croûte-manteaux et genese du plutonisme subalcalin du Haut Dauphiné occidental (Massifs cristallins externs): Vaugnérites, durbachites et granitoides magnésio-potassiques. Géol Alp 63: 95-117.

Barca D, Cirrincione R, De Vuono E, Fiannacca P, Ietto F, Lo Giudice A. 2010. The Triassic rift system in the northern CalabrianPeloritani Orogen: Evidence from basaltic dyke magmatism in the San Donato Unit. Period Mineral 79(2): 61-72. DOI: 10.2451/ 2010 PM0010.

Bauve V, Plateaux R, Rolland Y, Sanchez G, Bethoux N, Delouis B, et al. 2014. Long-lasting transcurrent tectonics in SW Alps evidenced by Neogene to present-day stress fields. Tectonophysics 621: 85-100. DOI: 10.1016/j.tecto.2014.02.006.

Bigot-Cormier F, Sosson M, Poupeau G, Stéphan JF, Larbin E. 2006. The denudation history of the Argentera Alpine External Crystalline Massif (Western Alps, France, Italy): An overview from the analysis of fission tracks in apatites and zircons. Geodin Acta 19(6): 455-473. DOI: 10.3166/ga.19.455-473.

Blasi A. 1968. Geo-petrologia della regione del Boréon (settore francese del Massiccio Cristallino dell 'Argentera). Università degli Studi di Milano, Master Thesis, p. 165.

Blasi A. 1971. Genesi dei noduli a sillimanite nelle anatessiti del Mt. Pélago (Alpi Marittime) in rapporto ai fenomeni di metamorfismo, piegamento e granitizzazione. Mem Soc Geol It 10(11): 167-190.

Bogdanoff S. 1986. Evolution de la partie occidentale du massif cristallin externe de l'Argentera. Place dans l'arc alpin. Géol France 4: 433-453.

Bogdanoff S, Ploquin A. 1980. Les gneiss et migmatites du massif de l'Argentera (Alpes maritimes); apport de deux coupes geochimiques. Bull Soc géol Fr 7(3): 353-358. DOI: 10.2113/ gssgfbull.S7-XXII.3.353.

Bogdanoff S, Michard A, Mansour M, Poupeau G. 2000. Apatite fission track analysis in the Argentera massif: Evidence of contrasting denudation rates in the External Crystalline Massifs of the Western Alps. Terra Nova 12(3): 117-125. DOI: 10.1046/ j.1365-3121.2000.123281.x.

Bortolami G, Sacchi R. 1968. Osservazioni geologico-petrografiche sui medi valloni di S. Anna e Rio Freddo (Massiccio Cristallino dell'Argentera). Mem Soc Geol It 7: 37-64.

Bortolami G, Callegari E, Gosso G. 1974. Caratteri metamorfici nella copertura permocarbonifera e nel basamento cristallino dell'Argentera. Mem Soc Geol It 13(1): 257-267.

Boucarut M. 1967. Structure du granite de l'Argentera et style tectonique de l'ensemble de ce massif. C R Acad Sci Paris 264: 1573-1576.

Buffet G, Aumaitre R. 1979. Implications tectoniques possibles des directions des filons carbonifères et triasiques de la partie Sud et Ouest du massif cristallin des Ecrins-Pelvoux. Géol Alp 55: 35-43.

Bussien D, Bussy F, Masson H, Magna T, Rodionov N. 2008. Variscan lamprophyres in the Lower Penninic domain (Central Alps): Age and tectonic significance. Bull Soc géol Fr 179(4): 369 381. DOI: $10.2113 /$ gssgfbull.179.4.369.

Bussy F, Hernandez J, Von Raumer JF. 2000. Bimodal magmatism as a consequence of the post-collisional readjustment of the thickened Variscan continental lithosphere (Aiguilles Rouges-Mont Blanc Massifs, Western Alps). Earth Env Sci Trans Roy Soc Edinb 91(1-2): 221-233. DOI: 10.1017/S0263593300007392.

Buzzi L, Gaggero L. 2008. Petrogenesis of post-orogenic Lower Permian andesites in southern Europe: Insights into the collapse of the Variscan range. Geodin Acta 21(5-6): 273-290. DOI: 10.3166/ ga.21.273-290.

Cannic S, Lapierre H, Monié P, Briqueu L, Basile C. 2002. Late orogenic evolution of the Variscan lithosphere: $\mathrm{Nd}$ isotopic constraints from the western Alps. Schweiz Mineral Petrogr Mitt 82: 77-99.

Carignan J, Hild P, Mevelle P, Morel J, Yeghicheyan D. 2001. Routine analyses of trace elements in geological samples using flow injection and low pressure on-line liquid chromatography coupled to ICP-MS: A study of geochemical reference materials BR, DR-N, UB-N, AN-G and GH. Geostandards Newslett 25(2-3): 187-198. DOI: 10.1111/j.1751-908X.2001.tb00595.x.

Carosi R, D'Addario E, Mammoliti E, Montomoli C, Simonetti M. 2016. Geology of the northwestern portion of the FerriereMollieres Shear Zone, Argentera Massif, Italy. J Maps 12(sup1): 466-475. DOI: 10.1080/17445647.2016.1243491.

Casetta F, Coltorti M, Marrocchino E. 2018. Petrological evolution of the Middle Triassic Predazzo Intrusive Complex, Italian Alps. Int Geol Rev 60(8): 977-997. DOI: 0.1080/00206814.2017.1363676. 
Casini L, Cuccuru S, Maino M, Oggiano G, Tiepolo M. 2012. Emplacement of the Arzachena Pluton (Corsica-Sardinia Batholith) and the geodynamics of incoming Pangaea. Tectonophysics 544: 31-49. DOI: 10.1016/j.tecto.2012.03.028.

Cassinis G, Cortesogno L, Gaggero L, Perotti C, Ronchi A. 2007. Volcanic products from the Early Permian Collio Basin (southern Alps) and their geodynamic implications. Period Mineral 76: 25-47. DOI: $10.2451 / 2007$ PM0007.

Cirrincione R, Fiannacca P, Lustrino M, Romano V, Tranchina A. 2014. Late Triassic tholeiitic magmatism in Western Sicily: A possible extension of the Central Atlantic Magmatic Province (CAMP) in the Central Mediterranean area?. Lithos 188: 60-71. DOI: 10.1016/j.lithos.2013.10.009.

Cirrincione R, Fiannacca P, Lustrino M, Romano V, Tranchina A, Villa IM. 2016. Enriched asthenosphere melting beneath the nascent North African margin: Trace element and $\mathrm{Nd}$ isotope evidence in middle-late Triassic alkali basalts from central Sicily (Italy). Int J Earth Sci (Geol Rundsch) 105(2): 595-609. DOI: 10.1007/s00531-015-1190-2.

Cocherie A, Rossi P, Fanning CM, Guerrot C. 2005. Comparative use of TIMS and SHRIMP for U-Pb zircon dating of A-type granites and mafic tholeiitic layered complexes and dykes from the Corsican Batholith (France). Lithos 82(1-2): 185-219. DOI: 10.1016/j.lithos.2004.12.016.

Colombo F, Ghiglione G, Compagnoni R. 1993. Relitti di porfidi granitici a xenoliti granulitici nelle migmatiti dell'Argentera (Alpi Marittime). Plinius 10: 113-116.

Compagnoni R, Ferrando S, Lombardo B, Radulesco N, Rubatto D. 2010. Paleo-European crust of the Italian western Alps: Geological history of the Argentera Massif and comparison with Mont BlancAiguilles Rouges and Maures-Tanneron Massifs. In: Beltrando M, Peccerillo A, Mattei M, Conticelli S, Doglioni C, eds. J Virt Expl 36 (paper 3): 1-32. DOI: 10.3809/jvirtex.2009.00228.

Corsini M, Ruffet G, Caby R. 2004. Alpine and late-hercynian geochronological constrains in the Argentera Massif (Western Alps). Eclogae Geol Helv 97: 3-15. DOI: 10.1007/ s00015-004-1107-8.

Cortesogno L, Cassinis G, Dallagiovanna G, Gaggero L, Oggiano G, Ronchi A, et al. 1998. The Variscan post-collisional volcanism in late Carboniferous-Permian sequences of Ligurian Alps, southern Alps and Sardinia (Italy): A synthesis. Lithos 45(1-4): 305-328. DOI: 10.1016/S0024-4937(98)00037-1.

Dallagiovanna G, Gaggero L, Maino M, Seno S, Tiepolo M. 2009. U$\mathrm{Pb}$ zircon ages for post-Variscan volcanism in the Ligurian Alps (Northern Italy). J Geol Soc 166(1): 101-114. DOI: 10.1144/ 0016-76492008-027.

Dardeau, G. 1988. Tethyan evolution and Alpine reactivation of Jurassic extensional structures in the French "Alpes Maritimes". Bull Soc géol Fr 4(4): 651-657. DOI: 10.2113/gssgfbull.IV.4.651.

Debon F, Le Fort P. 1988. A cationic classification of common plutonic rocks and their magmatic associations: Principles, method, applications. Bull Minéral 111(5): 493-510.

Debon F, Lemmet M. 1999. Evolution of Mg/Fe ratios in late Variscan plutonic rocks from the external crystalline massifs of the Alps (France, Italy, Switzerland). J Petrol 40(7): 1151-1185. DOI: 10.1093/petroj/40.7.1151.

Delteil J, Stephan JF, Attal M. 2003. Control of Permian and Triassic faults on Alpine basement deformation in the Argentera massif (external southern French Alps). Bull Soc géol Fr 174(5): 481-496. DOI: 10.2113/174.5.481.

Duchesne JC, Liégeois JP, Bolle O, Vander Auwera J, Bruguier O, Matukov DI, et al. 2013. The fast evolution of a crustal hot zone at the end of a transpressional regime: The Saint-Tropez peninsula granites and related dykes (Maures Massif, SE France). Lithos 162: 195-220. DOI: 10.1016/j.lithos.2012.12.019.

Evans MJ, Elliot T. 1999. Evolution of a thrust-sheet-top basin: The Tertiary Barrême Basin, Alpes de Haute Provence, France. Geol Soc Am Bull 111: 1617-1643. DOI: 10.1130/0016-7606(1999) $111<1617$ :EOATST $>2.3 . \mathrm{CO} ; 2$.

Faure-Muret A. 1955. Études géologiques sur le Massif de l'Argentera-Mercantour et sur ses enveloppes sédimentaires. Paris : Mém Carte Géol France, p. 336.

Ferrando S, Lombardo B, Compagnoni R. 2008. Metamorphic history of HP mafic granulites from the Gesso-Stura Terrain (Argentera Massif, Western Alps, Italy). Eur J Mineral 20: 777-790. DOI: 10.1127/0935-1221/2008/0020-1891.

Ferrara G, Malaroda R. 1969. Radiometric age of granitic rocks from the Argentera Massif (Maritime Alps). Boll Soc Geol It 88: $311-$ 320.

Ford M, Lickorish WH, Kusznir NJ. 1999. Tertiary foreland sedimentation in the southern Subalpine chains, SE France: A geodynamic analysis. Basin Res 11: 315-336. DOI: 10.1046/ j.1365-2117.1999.00103.x.

Frost BR, Barnes CG, Collins WJ, Arculus RJ, Ellis DJ, Frost CD. 2001. A geochemical classification for granitic rocks. J Petrol 42 (11): 2033-2048. DOI: 10.1093/petrology/42.11.2033.

Gaggero L, Oggiano G, Buzzi L, Slejko F, Cortesogno L. 2007. PostVariscan mafic dykes from the late orogenic collapse to the Tethyan rift: Evidence from Sardinia. Ofioliti 32(1): 15-37. DOI: 10.4454/ ofioliti.v32i1.344.

Garuti G, Bea F, Zaccarini F, Montero P. 2001. Age, geochemistry and petrogenesis of the ultramafic pipes in the Ivrea Zone, NW Italy. $J$ Petrol 42(2): 433-457. DOI: 10.1093/petrology/42.2.433.

Giobbi Origoni E, Bocchio R, Boriani A, Carmine M, De Capitani L. 1988. Late-Hercynian mafic and intermediate intrusives of Serie dei Laghi (N-Italy). Rend Soc It Mineral Petrol 43: 395-410.

Gosso G, Rebay G, Roda M, Spalla MI, Tarallo M, Zanoni D, et al. 2015. Taking advantage of petrostructural heterogeneities in subduction-collisional orogens, and effect on the scale of analysis. Period Mineral 84(3B Special Issue): 779-825. DOI: 10.2451/ 2015 PM0452.

Gosso G, Lardeaux JM, Zanoni D, Volante S, Corsini M, Bersezio R, et al. 2019. Mapping the progressive geologic history at the junction of the Alpine mountain belt and the western Mediterranean ocean. Ofioliti 44(2): 97-110. DOI: 10.4454/ofioliti. v44i2.467.

Kerckhove C. 1969. La Zone du flysch dans les nappes de l'Embrunais-Ubaye (Alpes occidentales). Géol Alp 45: 5-204.

Lapierre H, Basile C, Dupuis V. 1999. Basaltes et trachytes permiens de l'Esterel (SE France); une serie tholeiitique transitionnelle epanchee pendant l'amincissement lithospherique. Bull Soc géol Fr 170(2): 253-265.

Lardeaux JM. 2014. Deciphering orogeny: A metamorphic perspective. Examples from European Alpine and Variscan belts. Part I: Alpine metamorphism in the western Alps. A review. Bull Soc géol Fr 185(2): 93-114. DOI: 10.2113/gssgfbull.185.2.93.

Lardeaux JM, Spalla MI. 1991. From granulites to eclogites in the Sesia zone (Italian Western Alps): A record of the opening and closure of the Piedmont ocean. J Metamorph Geol 9: 35-59. DOI: 10.1111/j.1525-1314.1991.tb00503.x.

Latouche L, Bogdanoff S. 1987. Évolution précoce du massif de l'Argentera : apport des eclogites et des granulites. Géol Alp 63: 151-164.

Le Maitre RW, Streckeisen A, Zanettin B, Le Bas MJ, Bonin B, Bateman P, eds. 2002. Igneous rocks: A classification and glossary of terms: Recommendations of the International Union of 
Geological Sciences Subcommission on the Systematics of Igneous Rocks. Cambridge: Cambridge University Press, p. 236.

Leclère H, Lacroix B, Fabbri O. 2014. Fault mechanics at the base of the continental seismogenic zone: Insights from geochemical and mechanical analyses of a crustal-scale transpressional fault from the Argentera crystalline massif, French-Italian Alps. J Struct Geol 66: 115-128. DOI: 10.1016/j.jsg.2014.05.009.

Lemoine M, Bas T, Arnaud-Vanneau A, Arnaud H, Dumont T, Gidon M, et al. 1986. The continental margin of the Mesozoic Tethys in the Western Alps. Mar Petroleum Geol 3(3): 179-199. DOI: 10.1016/0264-8172(86)90044-9.

Leroy S, Cabanis B. 1993. Le volcanisme permien du bassin de Toulon : un jalon septentrional du volcanisme permien de l'Ouest méditerranéen. Geol Fr 2: 57-66.

Locmelis M, Fiorentini ML, Rushmer T, Arevalo Jr R, Adam J, Denyszyn SW. 2016. Sulfur and metal fertilization of the lower continental crust. Lithos 244: 74-93. DOI: 10.1016/j.lith os.2015.11.028.

Malaroda R, Carraro F, Dal Piaz GV, Franceschetti B, Sturani C, Zanella E. 1970. Carta geologica del Massiccio dell'Argentera alla scala 1:50000 e note illustrative. Mem Soc Geol It 9: 557-663.

Marotta AM, Spalla MI, Gosso G. 2009. Upper and lower crustal evolution during lithospheric extension: Numerical modelling and natural footprints from the European Alps. In: Ring U, Wernicke B, eds. Extending a continent: Architecture, rheology and heat budget. Geol Soc London Spec Publ 321: 33-72. DOI: $10.1144 /$ SP321.3.

Marotta AM, Roda M, Conte K, Spalla MI. 2018. Thermo-mechanical numerical model of the transition from continental rifting to oceanic spreading: The case of study of the Alpine Tethys. Geol Mag 155(2): 250-279. DOI: 10.1017/S0016756816000856.

Maruyama S, Liou JG, Suzuki K. 1982. The peristerite gap in lowgrade metamorphic rocks. Contrib Mineral Petrol 81(4): 268-276. DOI: $10.1007 / \mathrm{BF} 00371681$.

Maruyama S, Suzuki K, Liou JG. 1983. Greenschist-amphibolite transition equilibria at low pressures. J Petrol 24(4): 583-604. DOI: $10.1093 /$ petrology/24.4.583.

Merle O, Brun JP. 1984. The curved translation path of the Parpaillon Nappe (French Alps). J Struct Geol 6(6): 711-719. DOI: 10.1016/ 0191-8141(84)90010-5.

Montani V. 2004. Studio meso e microstrutturale dei boudin di metabasiti del complesso Malinvern-Argentera: resti dell'Oceano Reico nel Dominio Provenzale delle Alpi Marittime. Università degli Studi di Milano, Master Thesis, p. 181.

Morillon AC, Féraud G, Sosson M, Ruffet G, Crevola G, Lerouge G. 2000. Diachronous cooling on both sides of a major strike slip fault in the Variscan Maures Massif (south-east France), as deduced from a detailed 40Ar/39Ar study. Tectonophysics 321(1): 103-126. DOI: 10.1016/S0040-1951(00)00076-7.

Mørk MBE. 1985. A gabbro to eclogite transition on Flemsøy, Sunnmøre, western Norway. Chem Geol 50(1-3): 283-310. DOI: 10.1016/0009-2541(85)90125-1.

Musumeci G, Colombo F. 2002. Late Visean mylonitic granitoids in the Argentera Massif (western Alps, Italy): Age and kinematic constraints on the Ferrière-Mollières shear zone. C R Geosci 334 (3): 213-220. DOI: 10.1016/S1631-0713(02)01722-4.

Myers JS. 1978. Formation of banded gneisses by deformation of igneous rocks. Precambrian Res 6(1): 43-64. DOI: 10.1016/ 0301-9268(78)90054-2.

Paquette JL, Ménot RP, Peucat JJ. 1989. REE, Sm-Nd and U-Pb zircon study of eclogites from the Alpine External Massifs (Western Alps): Evidence for crustal contamination. Earth Planet Sci Lett 96: 181-198. DOI: 10.1016/0012-821X(89)90131-3.
Paquette JL, Ménot RP, Pin C, Orsini JB. 2003. Episodic and shortlived granitic pulses in a post-collisional setting: Evidence from precise $\mathrm{U}-\mathrm{Pb}$ zircon dating through a crustal cross-section in Corsica. Chem Geol 198(1-2): 1-20. DOI: 10.1016/S0009-2541 (02)00401-1.

Poitrasson F, Pin C. 1998. Extreme Nd isotope homogeneity in a large rhyolitic province: The Estérel massif, southeast France. Bull Volcanol 60(3): 213-223. DOI: 10.1007/s004450050228.

Renna MR, Tribuzio R, Tiepolo M. 2007. Origin and timing of the post-Variscan gabbro-granite complex of Porto (Western Corsica). Contrib Mineral Petrol 154(5): 493-517. DOI: 10.1007/ s00410-007-0205-9.

Roda M, Regorda A, Spalla MI, Marotta AM. 2018. What drives Alpine Tethys opening? Clues from the review of geological data and model predictions. Geol J 2018: 1-19. DOI: 10.1002/gj.3316.

Romain J, Vernet J. 1978. Decouverte d'un volcanisme basique d'age permien dans la vallee de la Gordolasque (Sud-Ouest du massif de l'Argentera-Mercantour, Alpes-Maritimes, France). Bull Soc géol Fr S7-XX(6): 929-933. DOI: 10.2113/gssgfbull.S7-XX.6.929.

Romano V, Cirrincione R, Fiannacca P, Lustrino M, Tranchina A. 2011. Late-Hercynian post-collisional dyke magmatism in central Calabria (Serre Massif, southern Italy). Period Mineral 80(3 Special Issue): 489-515. DOI: 10.2451/2011PM0032.

Rossi P, Cocherie A, Lahondère D, Fanning CM. 2002. The European margin of the Jurassic Tethys in Corsica: Dating of Balagne trondhjemites and evidence to support a continental crust beneath the Balagne-Ligurian domain. CR Geosci 334(5): 313-322. DOI: 10.1016/S1631-0713(02)01758-3.

Rossi P, Cocherie A, Fanning CM. 2015. Evidence in Variscan Corsica of a brief and voluminous Late Carboniferous to Early Permian volcanic-plutonic event contemporaneous with a hightemperature/low-pressure metamorphic peak in the lower crust. Bull Soc géol Fr 186(2-3): 171-192. DOI: 10.2113/ gssgfbull.186.2-3.171.

Rottura A, Bargossi GM, Caggianelli A, Del Moro A, Visona D, Tranne CA. 1998. Origin and significance of the Permian high-K calc-alkaline magmatism in the central-eastern Southern Alps, Italy. Lithos 45(1-4): 329-348. DOI: 10.1016/S0024-4937(98) 00038-3.

Rubatto D, Schaltegger U, Lombardo B, Colombo F, Compagnoni R. 2001. Complex Paleozoic magmatic and metamorphic evolution in the Argentera Massif (Western Alps), resolved with U-Pb dating. Schweiz Mineral Petrogr Mitt 81: 213-228. DOI: 10.5169/seals61689.

Rubatto D, Ferrando S, Compagnoni R, Lombardo B. 2010. Carboniferous high-pressure metamorphism of Ordovician protoliths in the Argentera Massif (Italy), Southern European Variscan belt. Lithos 116(1-2): 65-76. DOI: 10.1016/j.lithos.2009.12.013.

Sanchez G, Rolland Y, Schreiber D, Giannerini G, Corsini M, Lardeaux JM. 2010. The active fault system of SW Alps. J Geodyn 49(5): 296-302. DOI: 10.1016/j.jog.2009.11.009.

Sanchez G, Rolland Y, Schneider J, Corsini M, Oliot E, Goncalves P, et al. 2011a. Dating low-temperature deformation by ${ }^{40} \mathrm{Ar} /{ }^{39} \mathrm{Ar}$ on white mica, insights from the Argentera-Mercantour Massif (SW Alps). Lithos 125(1): 521-536. DOI: 10.1016/j.lithos.2011.03.009. Sanchez G, Rolland Y, Jolivet M, Brichau S, Corsini M, Carter A. 2011b. Exhumation controlled by transcurrent tectonics: The Argentera-Mercantour massif (SW Alps). Terra Nova 23(2): 116126. DOI: 10.1111/j.1365-3121.2011.00991.x.

Schaltegger U, Brack P. 2007. Crustal-scale magmatic systems during intracontinental strike-slip tectonics: $\mathrm{U}, \mathrm{Pb}$ and $\mathrm{Hf}$ isotopic constraints from Permian magmatic rocks of the Southern Alps. Int JEarth Sci 96(6): 1131-1151. DOI: 10.1007/s00531-006-0165-8. 
Schreiber D, Lardeaux JM, Martelet G, Courrioux G, Guillen A. 2010. 3-D modelling of Alpine Mohos in Southwestern Alps. Geophys J Int 180: 961-975. DOI: 10.1111/j.1365-246X.2009.04486.x.

Schwartz S, Lardeaux JM, Tricart P, Guillot S, Labrin E. 2007. Diachronous exhumation of HP-LT metamorphic rocks from southwestern Alps: Evidence from fission track analysis. Terra Nova 19 (2): 133-140. DOI: 10.1111/j.1365-3121.2006.00728.x.

Simon-Labric T, Rolland Y, Dumont T, Heymes T, Authemayou C, Corsini M, et al. 2009. ${ }^{40} \mathrm{Ar} /{ }^{39} \mathrm{Ar}$ dating of Penninic Front tectonic displacement (WAlps) during the Lower Oligocene (31-34 Ma). Terra Nova 21(2): 127-136. DOI: 10.1111/j.1365-3121.2009.00865.x.

Simonetti M, Carosi R, Montomoli C, Langone A, D'Addario E, Mammoliti E. 2018. Kinematic and geochronological constraints on shear deformation in the Ferriere-Mollières shear zone (Argentera-Mercantour Massif, Western Alps): Implications for the evolution of the Southern European Variscan Belt. Int J of Earth Sci 107: 2163-2189. DOI: 10.1007/s00531-018-1593-y.

Sloman LE. 1989. Triassic shoshonites from the dolomites, northern Italy: Alkaline arc rocks in a strike-slip setting. J Geophys Res Solid Earth 94(B4): 4655-4666. DOI: 10.1029/JB094iB04p04655.

Spalla MI, Siletto GB, di Paola S, Gosso G. 2000. The role of structural and metamorphic memory in the distinction of tectonometamorphic units: The basement of the Como lake in the Southern Alps. J Geodyn 30(1-2): 191-204. DOI: 10.1016/S0264-3707(99) 00033-2.

Spalla MI, Zanoni D, Marotta AM, Rebay G, Roda M, Zucali M, et al. 2014. The transition from Variscan collision to continental breakup in the Alps: Insights from the comparison between natural data and numerical model predictions. In: Schulmann K, Martínez Catalán JR, Lardeaux JM, Janoušek V, Oggiano G, eds. The Variscan Orogeny: Extent, Timescale and the Formation of the European Crust. Geol Soc London Spec Publ 405: 363-400. DOI: 10.1144/SP405.11.

Spear FS. 1993. Metamorphic phase equilibria and pressure-temperature-time paths. Washington D.C.: Min Soc Am Monograph, p. 799.

Storck JC, Brack P, Wotzlaw JF, Ulmer P. 2019. Timing and evolution of Middle Triassic magmatism in the Southern Alps (northern Italy). J Geol Soc 176(2): 253-268. DOI: 10.1144/jgs2018-123.

Sun SS, McDonough WF. 1989. Chemical and isotopic systematics of oceanic basalts: Implications for mantle composition and processes. In: Saunders AD, Norry MJ, eds. Magmatism in the ocean basins. Geol Soc London Spec Publ 42: 313-345. DOI: 10.1144/GSL.SP.1989.042.01.19.

Traversa G, Ronca S, Del Moro A, Pasquali C, Buraglini N, Barabino G. 2003. Late to post-Hercynian dyke activity in the Sardinia-Corsica domain: A transition from orogenic calc-alkaline to anorogenic alkaline magmatism. Boll Soc Geol It 2: 131-152.

Tricart P, Schwartz S, Sue C, Lardeaux JM. 2004. Evidence of synextension tilting and doming during final exhumation from analysis of multistage faults (Queyras Schistes lustrés, Western Alps). J Struct Geol 26(9): 1633-1645. DOI: 10.1016/j.jsg.2004.02.002.

Vatin-Pérignon N, Aumaitre R, Buffet G. 1974. La spilitisation dans le massif des Écrins-Pelvoux Un cortège intrusif et effusif doléritospilitique. Géol Alp 50: 153-194.

Vatin-Pérignon N, Juteau T, Le Fort P. 1972. Les filons du massif du Pelvoux (Alpes occidentales françaises). Géol Alp 48: 207-227.

Vernon RH. 2018. A practical guide to rock microstructures, second edition. Cambridge: Cambridge University Press, p. 432. DOI: 10.1017/9781108654609.

von Raumer JF. 1987. Les Massifs du Mont Blanc et des Aiguilles Rouges temoins de la formation de croute Varisque dans les Alpes Occidentales. Géol Alp 63: 7-24.

von Raumer JF, Finger F, Veselà P, Stampfli GM. 2014. DurbachitesVaugnerites - a geodynamic marker in the central European Variscan orogen. Terra Nova 26: 85-95. DOI: 10.1111/ter.12071.

Whitney DL, Evans B. 2010. Abbreviations for names of rockforming minerals. Am Mineral 95(1): 185-187. DOI: 10.2138/ am.2010.3371.

Williams PF. 1985. Multiply deformed terrains - problems of correlation. J Struct Geol 7(3-4): 269-280. DOI: 10.1016/0191-8141(85) 90035-5.

Zanoni D, Spalla MI. 2018. The Variscan evolution in basement cobbles of the Permian Ponteranica Formation by microstructural and petrologic analysis. Ital J Geosci 137: 254-271. DOI: 10.3301/ IJG.2018.12.

Zanoni D, Rebay G, Spalla MI. 2016. Ocean floor and subduction record in the Zermatt-Saas rodingites, Valtournanche, Western Alps. J Metamorph Geol 34: 941-961. DOI: 10.1111/jmg. 12215.

Zheng JS, Mermet JF, Toutin-Morin N, Hanes J, Gondolo A, Morin R, et al. 1992. Datation ${ }^{40} \mathrm{Ar}-{ }^{39} \mathrm{Ar}$ du magmatisme et de filons minéralisés permiens en Provence orientale (France). Geodin Acta 5(3): 203-215. DOI: 10.1080/09853111.1992.11105228.

Cite this article as: Filippi M, Zanoni D, Gosso G, Lardeaux J-M, Verati C, Spalla MI. 2019. Structure of lamprophyres: a discriminant marker for Variscan and Alpine tectonics in the Argentera-Mercantour Massif, Maritime Alps, BSGF - Earth Sciences Bulletin 190: 12. 